\title{
The Kalahari Craton during the assembly and dispersal of Rodinia
}

\author{
J. Jacobs ${ }^{1}$, S. Pisarevsky ${ }^{2,3}$, R.J. Thomas ${ }^{4}$, T. Becker ${ }^{5}$
}

1) Department of Earth Science, University of Bergen, Allegaten 41, 5007 Bergen, joachim.jacobs@geo.uib.no

2) Tectonics Special Research Centre, Univ. of Western Australia, Crawley WA 6009, Australia

3) School of Geosciences, The University of Edinburgh, Grant Institute, King's Buildings, West Mains Road, Edinburgh, EH9 3JW, UK

4) British Geological Survey, Keyworth, Nottingham, NG12 5GG, UK

5) BRGM, BP 6009, 45060 Orleans CEDEX 2, France

\begin{abstract}
In this paper we review the dimensions, geometry and architecture of the components of the Kalahari Craton and the various positions this important crustal block could have occupied within Rodinia. The Kalahari Craton was spawned from a small composite Archaean core which grew by prolonged crustal accretion in the Palaeoproterozoic along its NW side (MagondiOkwa-Kheis belt, Rehoboth Subprovince) to form the Proto-Kalahari Craton by $1750 \mathrm{Ma}$. From ca. 1400-1000 Ma, all margins of this crustal entity recorded intense tectonic activity: the NW margin was a major active continental margin between ca. 1400 and $1200 \mathrm{Ma}$ and along the southern and eastern margins, the Namaqua-Natal-Maud-Mozambique belt records a major arc-accretion and continent-collision collision event between ca. 1100 and 1050 Ma. By ca. $1050 \mathrm{Ma}$, the Proto-Kalahari nucleus was almost completely rimmed by voluminous Mesoproterozoic crust and became a larger entity, the Kalahari Craton. Apart from southern Africa, fragments of the Kalahari Craton are now exposed in East- and West-Antarctica, the Falkland Islands and possibly also in South America. Immediately prior to the onset of arc- and continent-continent collision along the Namaqua-Natal-Maud Belt (part of the widespread "Grenville-age" orogeny during which Rodinia was assembled), Kalahari was subjected to intraplate magmatism - the Umkondo-Borg Large Igneous Province - at ca. $1110 \mathrm{Ma}$. The postRodinia rift and drift history of the Kalahari Craton is best preserved along the western, southwestern and north-western margin, where rift sediments and volcanics indicate rifting and break-up at ca. 800-750 Ma. The position of the Kalahari Craton in Rodinia is problematic, and there is no unique solution for its placement in the supercontinent. One set of models has the Kalahari Craton lying along the SW side of Laurentia with the Namaqua-Natal-Maud belt facing either inboard (correlation with the Ottawan cycle of the Grenville orogen) or outboard (mainly for palaeomagnetic reasons). In this arrangement the relatively late rift history and the subsequent incorporation of Kalahari into Gondwana is problematic. Alternatively, Kalahari could have been attached to Western Australia. In this model the Namaqua-Natal-Maud belt has no counterpart and, although the timing of rifting at ca. $750 \mathrm{Ma}$ fits, the location of rifting is problematic - the Kalahari Craton would have had to undergo major rifting along its eastern, rather than its western side, which is not consistent with overservations. So the matter is as yet unresolved, and much of the evidence of rifting along the eastern side of the Kalahari Craton was obliterated due to high-grade overprint along the Late Neoproterozoic/Early Palaeozoic East African-Antarctic Orogen.
\end{abstract}

Keywords: Kalahari Craton, Rodinia, palaeomagnetism, supercontinent 


\section{Introduction}

It is almost 40 years since Clifford (1970) first coined the term Kalahari Craton for the Precambrian shield of Southern Africa. This concept was developed by Hartnady et al. (1985), who envisaged a Kalahari Craton made up of crustal components of different ages, comprising a composite Archaean nucleus partly surrounded by progressively younger accreted belts of Palaeoproterozoic and Mesoproterozoic age (Fig. 1). In contrast to this definition, however, a number of authors have used Kalahari Craton for the crust that existed prior to amalgamation into Rodinia, BUT without the extensive Mesoproterozoic rim (e.g. Dalziel, 1991; Powell et al., 2001a). The term Kalahari Craton has never included the Late Neoproterozoic/Early Palaeozoic ("Pan-African") belts, which were subsequently accreted to the older core.

In the late 1980's it became clear that pre-Neoproterozoic crustal fragments, now residing in other continents, might have been contiguous with the southern African part of the Kalahari Craton and subsequently dispersed during the Mesozoic break-up of Gondwana (Martin and Hartnady, 1986; Groenewald et al., 1991). For example, the Archaean and Mesoproterozoic crust of Western Dronning Maud Land, East Antarctica, was probably juxtaposed against the eastern part of the "African" Kalahari Craton prior to Gondwana break-up (e.g. Groenewald et al., 1991). Consequently, there is a need to exactly define the term Kalahari Craton. In defining a "craton" as a once-continuous fragment of stabilised continental crust, the Kalahari Craton should encompass all fragments of crust (up to Mesoproterozoic age) of "African" affinity, that were juxtaposed prior to the Neoproterozoic. We do not restrict the term to those areas with a thick lithospheric root, which would only include the Archaean nucleus.

In the 1990's it was proposed that the extensive Mesoproterozoic collision belts of the world (including the Grenville Orogen) represent the amalgamation of a pre-Gondwana supercontinent, which was named Rodinia. This major collision orogen included the belts of southern Africa and East Antarctica - the outer "rim" of the Kalahari Craton. It thus appeared that the crustal fragments constituting the "Kalahari Craton" were involved in the assembly and dispersal of two supercontinent cycles, Rodinia in the Mesoproterozoic and Gondwana in the Neoproterozoic, giving rise to a complex history of growth and accretion, rifting and dispersal.

In this paper we propose a workable definition of the Kalahari Craton and briefly describe its architecture and growth from Archaean to Mesoproterozoic time when it was incorporated into, and formed as one of the larger fragments of, Rodinia. To illustrate this we present a series of time-slice diagrams, which purport to show the broad "palaeogeography" of the evolving craton and its margins. We review the available palaeomagnetic data from the various fragments of the Kalahari Craton in order to trace its palaeoposition over time and to test which other cratonic fragments may have been adjacent to it in Rodinia, prior to final break-up and separation from Rodinia in the Neoproterozoic.

Consequently, we propose using the terms "Proto-Kalahari Craton" for the ArchaeanPalaeoproterozoic core of the craton and "Kalahari Craton" for the African part of the Kalahari Craton as originally defined (i.e. including Mesoproterozoic crust), plus the various non-African fragments that together probably constituted a single crustal fragment during the assembly of Rodinia (Fig. 1). These include smaller fragments now near South America (Falkland Islands), different parts of Antarctica (Dronning Maud Land, Haag Nunataks) and possible further, as yet 
unidentified, fragments elsewhere (e.g. in South America). The margins of the Kalahari Craton thus defined, are surrounded, and to various degrees overprinted, by late Neoproterozoic/early Palaeozoic ("Pan-African") mobile belts. In view of these features, estimates of the size and geometry of the pre-Pan-African Kalahari Craton are difficult, but it follows that the craton was significantly larger than shown in most Rodinia reconstructions, with consequent implications for these reconstructions. The localisation of the (assumed) bounding suture zones of the Kalahari Craton is also difficult due to later (Pan-African) tectono-metamorphic overprinting. We use the present-day African geographic co-ordinate system for the descriptive part of the various Kalahari configurations in the following palaeogeographic cartoons.

\section{1) From the Zimbabwe-Kaapvaal-Grunehogna (ZKG) Craton to the Proto- Kalahari Craton}

The Proto-Kalahari Craton in the Palaeo- to early Mesoproterozoic is depicted in Fig. 2. It comprises an Archaean crustal core along with accreted Palaeoproterozoic rocks, which were assembled by ca. $1750 \mathrm{Ma}$. The Archaean core is composite, formed by the Zimbabwe and Kaapvaal cratons, which amalgamated along the Limpopo Province (e.g. de Wit et al., 1992), and a fragment of the Kalahari Craton, which is now exposed in western Dronning Maud Land (East Antarctica) and known as the Grunehogna Craton. Geophysical data have helped to elucidate the size, shape and internal structure of the Archaean nuclei (e.g. Corner, 1991). Additionally, palaeomagnetic data indicate that, at least during latest Mesoproterozoic times, the Kaapvaal and Grunehogna blocks likely formed a single entity (e.g. Peters et al., 1991; Gose et al., 1997; Jones et al., 2003).

The western and northern margins of the Archaean nucleus are extremely poorly exposed under younger cover rocks of the Kalahari Desert. Nevertheless, from isolated outcrops, boreholes and geophysical evidence it is known that the ZKG Craton is juxtaposed against Palaeoproterozoic rocks of the Kheis, Okwa and Magondi sequences (Singletary et al., 2003, Hanson, 2003, and references therein). In the Magondi Belt (Fig. 2), a sequence of volcanosedimentary rocks up to $5 \mathrm{~km}$ thick, together with minor older basement, has been deformed and metamorphosed to medium-grade conditions. Syntectonic granitoids of this belt gave $\mathrm{U}-\mathrm{Pb}$ zircon crystallisation ages of ca. $1950 \mathrm{Ma}$ (Munyanyiwa et al., 1995). It has been suggested that the protolith of the Magondi Belt evolved within and along an island-arc/back-arc complex that finally collided with, and was thrust onto, the ZKG Craton (Master, 1991). The Magondi Belt is correlated beneath extensive younger cover with the fault-bounded Okwa Block to the southwest, where similar orthogneisses and metarhyolites are exposed (e.g. Ramokate et al., 2000). Further south, Palaeoproterozoic volcano-sedimentary rocks (Kheis Province) crop out, along with reworked Archaean basement (e.g. Moen, 1999 and references therein), which represents an East-vergent fold and thrust belt onto the Archaean craton (Hartnady et al., 1985). The age of metamorphism within the Kheis Province is poorly constrained, but it is younger than in the Magondi Belt. The western boundaries of the Kheis-Okwa outcrops are marked by a distinct, but unexposed, north-south geophysical lineament, which might represent a Palaeoproterozoic thrust zone (Mason et al., 1998). West of this lineament, in Namibia, the Rehoboth Subprovince forms a geophysically distinct, but extremely poorly exposed entity west of the Kheis-OkwaMagondi rocks. It is only the extreme NE parts of this vast area, which give clues as to the 
nature of the underlying crust. In the Rehoboth area of central Namibia, migmatitic orthogneisses, dated at $1784 \pm 45 \mathrm{Ma}$ (Burger and Walraven, 1978) are overlain by an at least $5 \mathrm{~km}$-thick succession of sheared and metamorphosed volcano-sedimentary rocks known as the Rehoboth Group (Becker et al., 2004). The volcanic component of this succession is juvenile in character and has given a conventional U-Pb zircon crystallisation age of $1782+10 /-$ $9 \mathrm{Ma}$ (Nagel et al., 1996). Deposition of the Rehoboth Group was accompanied and followed by major plutonism ranging in composition from ultramafic to mafic (Alberta layered complexes) through intermediate (Weener tonalite) to granitic (Piksteel Suite) at ca. 1780-1765 Ma (Burger and Walraven, 1978; Becker et al., 1996; 2004). The geology of the Rehoboth Group is considered to reflect the transition from a volcanic arc into a back arc setting (Becker et al. 2004). The regional metamorphic event coinciding with the timing of calc-alkaline magmatism has been explained by arc accretion which, at the end of the Palaeoproterozoic, marked the completion of the assembly of the Proto-Kalahari Craton.

Further south, Palaeoproterozoic arc-related volcanic and plutonic rocks occur in the Richtersveld Subprovince. These consist of a low-grade (greenschist facies) volcanosedimentary sequence, the Orange River Group, which is intruded by co-genetic, coeval plutonic rocks (Vioolsdrif Suite) with juvenile island-arc geochemistry and ages bracketed between 2000 and 1730 Ma (Reid, 1997). It is unclear if the rocks of the Richtersveld Subprovince formed in this location or if they represent part of a microcontinental mass accreted during the Mesoproterozoic. It is similarly unknown if the high-grade basement to much of the Mesoproterozoic Namaqua Sector, which is known to be at least partially Palaeoproterozoic in age (e.g. Eglington and Armstrong, 2004), originated within southern Africa or if these rocks represent parts of exotic fragments accreted during the Mesoproterozoic. Notwithstanding these unknowns, the end of the Palaeoproterozoic marked the beginning of a long period of tectonic quiescence in the geological record of this region. No evidence of Palaeoproterozoic activity is recorded from the SE flanks of the ZKG Craton.

\section{2) From the Proto-Kalahari Craton to the Kalahari Craton}

After over $350 \mathrm{Ma}$ of apparent quiescence around the margins of the Proto-Kalahari Craton, renewed tectonic activity during the Mesoproterozoic heralded a major period of crustal growth, during which the area of the Proto-Kalahari Craton almost doubled from ca. $7 \times 10^{6}$ to $13 \times 10^{6}$ $\mathrm{km}^{2}$ (Fig. 3).

\section{The north-western margin: a Mesoproterozoic continental arc}

Outboard of the accreted Palaeoproterozoic terranes, the NW flank again became an active continental margin at ca. $1400 \mathrm{Ma}$. Low-grade Mesoproterozoic volcanic and sedimentary rocks occur in a series of poorly-exposed inliers which appear to have been deposited in basins aligned along the western and north-western margins of Proto-Kalahari. These define a magmatic province that, if all the outcrops are considered, measured more than $1000 \mathrm{~km}$ in length (Fig. 3). It includes the Kgwebe Formation of Botswana and the Sinclair and Nauzerus groups of Namibia (Becker et al. 2006 and references therein). The Sinclair Group includes four thick, conformable volcano-sedimentary cycles deposited in north-south elongated basins (Watters, 1974; Borg, 1988; Hoal, 1990; 1993). These thick sequences are dominated by 
bimodal volcanic rocks and epicontinental sedimentary clastic rocks. These are mildly deformed and were subsequently intruded by calc-alkaline granite suites of batholithic dimensions, with subordinate gabbro and granodiorite. The minimum age of the lower part of the Sinclair Group in southern Namibia is constrained by the intrusion of the arc-related Aunis tonalite at about $1376 \mathrm{Ma}$ (Hoal and Heaman, 1995).

Late-Mesoproterozoic volcanosedimentary rocks crop out in the Rehoboth area of central Namibia, and in Botswana, parallel to the north-western margin of the Proto-Kalahari Craton. The sequence consists of low-grade metasedimentary rocks and acid volcanics which have given dates ranging from ca. $1225 \mathrm{Ma}$ up to ca. $1100 \mathrm{Ma}$ (Hegenberger and Burger, 1985; Schwartz et al., 1996; Schneider et al., 2004; Becker et al. 2005).

The origin of the Mesoproterozoic basins of north-west Kalahari remains controversial. A variety of settings have been proposed, most of which involve subduction-related active continentalmargin settings (e.g. Hoal, 1990; Pfurr et al., 1991; Hoal and Heaman, 1995, Becker et al., 2005, 2006).

\section{The southern and eastern margins: a major Mesoproterozoic orogenic belt}

The Namaqua-Natal-Maud Province forms a major continuous belt of high-grade rocks that has been modeled as resulting from continent-continent and/or arc-continent- collision, with indentation-escape tectonics along the south-western, southern, south-eastern and eastern side of Proto-Kalahari between $\sim 1.2$ to $1.0 \mathrm{Ga}$ (e.g. Jacobs et al., 1993; Thomas et al., 1994; Fig. 3). In southern Africa, the province is exposed in two areas of outcrop known as the "Namaqua Sector" (in the Northern Cape Province of South Africa and southern Namibia) and the "Natal Sector" (in Kwazulu-Natal). Regional geophysical data, together with crustal xenolith evidence from kimberlite diatremes in Lesotho and deep boreholes, show that the two sectors are the exposed parts of a continuous, $1400 \times 400 \mathrm{~km}$ wide, arcuate orogenic belt extending beneath the Phanerozoic Karoo Supergroup of central South Africa (Fig. 4). Both sectors of the province are subdivided into various tectono-stratigraphic blocks, defined by distinctive lithostratigraphic packages bounded by structural discontinuities. The belt can then be traced via the Falkland and Ellsworth-Haag microplates into Dronning Maud Land (East Antarctica) and thence probably northwards into NE Mozambique.

\section{Namaqua Sector}

The Namaqua Sector of the Namaqua-Natal Province comprises a number of subprovinces and terranes, the definitions and boundaries of which remain controversial. The main crustal units recognized are the Richtersveld Subprovince and the Bushmanland, Kakamas, Areachap and Kaaien terranes. These terranes are bound by late Mesoproterozoic shear zones. The Richtersveld Subprovince represents a Palaeoproterozoic arc terrain within the Namaqua Sector that largely escaped Mesoproterozoic reworking (Reid, et al., 1987). As noted before it is not known if this crustal fragment formed in its present position, or evolved elsewhere and was accreted as a micro-continental block during the Mesoproterozoic. Similarly, the vast proportion of the Namaqua Sector include a high (but unknown) proportion of Palaeoproterozoic rocks that were deformed, subjected to high-grade metamorphism and intruded by voluminous granitoids during the Mesoproterozoic collision. The latter are generally of granite to charnockite 
composition, ranging in age from ca. 1200 to $1030 \mathrm{Ma}$ (e.g. Robb et al., 1999). It appears that only the relatively small Areachap terrane (Fig. 4) is made up of almost entirely juvenile Mesoproterozoic crust with subduction-related signatures and an age of ca. 1285 Ma (e.g. Cornell et al., 1992, Geringer et al., 1994). Recent work however cast doubt on the extent to which Palaeoproterozoic crust forms the "basement" in Namaqualand (e.g. Cornell and Pettersson, 2007). In the Eastern Namaqua sector, the Koras Group comprises an approximately $7000 \mathrm{~m}$ thick succession of bimodal volcanics and immature sedimentary rocks that unconformably overlie the Kheis and Namaqua belts. The sequence is largely undeformed, underwent only very low-grade metamorphism, and was SHIRMP zircon dated at $1171 \pm 7 \mathrm{Ma}$ (Gutzmer et al., 2000).

Structurally, the Mesoproterozoic history of the Namaqua Sector is dominated by SW-directed crustal stacking, followed by prolonged dextral transpressional tectonics (e.g. Colliston et al., 1991; Van Bever Donker, 1991; Jacobs et al., 1993). The Koras Group represents deposition in a rift basin, which might have evolved within a dextral pull-apart type setting during oblique shearing along the margin of the Namaqua Belt (Jacobs et al., 1993).

\section{Natal Sector}

The Natal Sector of the Namaqua-Natal Province comprises three distinct tectono-stratigraphic terranes (Thomas, 1989; Thomas et al., 1994) that were thrust NE over the southern margin of the Kaapvaal Craton at about 1135 (Jacobs et al., 1997). The terranes are made up of juvenile Mesoproterozoic crust (Eglington et al., 1989; Eglington, 2006), which probably formed in island-arcs crust that evolved during subduction away (southwards) from the Kaapvaal Craton between ca. 1250 and $1100 \mathrm{Ma}$ (see review, McCourt et al., 2006). Arc-continent collision was oblique and resulted, after initial crustal thickening, in sinistral transpression and crustal escape tectonics along major ductile shear zones (Jacobs and Thomas, 1994). This event was accompanied by the widespread intrusion of rapakivi-textured granitoids and charnockites in a transcurrent tectonic setting, associated with high- $\mathrm{T}$, moderate-P granulite-grade metamorphism between 1070 and 1030 Ma (e.g. Thomas et al., 1993, Eglington and Armstrong, 2004; Eglington, 2006). The youngest intrusions in Natal are microgranite dykes which were emplaced at ca. $1020 \mathrm{Ma}$ (Thomas et al., 1994), though low-temperature thermal perturbations as young as $900 \mathrm{Ma}$ are recorded (Jacobs et al., 1997).

Jacobs et al. (1993) pointed out that Proto-Kalahari probably acted as a SW-directed indenter during the accretion of the Namaqua-Natal Province during Mesoproterozoic times (1.2 to 1.0 $\mathrm{Ga}$ ) and that the contrasting late-tectonic transcurrent shearing along the craton margin in the Namaqua and Natal sectors are a function of the varying orientation of the craton margin, resulting in sinistral transpression in Natal and in dextral transpression in Namaqualand.

\section{Falkland Islands and Haag Nunataks}

The Falkland Islands represent the exposed part of the Falkland-Malvinas Plateau, a crustal fragment that in Gondwana and Rodinia, most probably lay between SE South Africa and East Antarctica (Fig. 1, 4). Its position along the SE coast of South Africa was proposed by Adie (1952) for purely geological reasons, although this position requires the rotation of the FalklandMalvinas microplate through $180^{\circ}$ with respect to its present position. This rotation was 
confirmed palaeomagnetically by Mitchell et al. (1986). This position suggests that the Falkland Island microplate probably formed part of the Kalahari Craton. Crystalline basement rocks are exposed in West Falkland along a $5 \mathrm{~km}$ coastal strip at Cape Meredith (Cingolani and Varela, 1976, Thomas et al., 1997). U-Pb zircon crystallisation ages of igneous rocks from the Cape Meredith Complex were dated between ca. 1120 - 1000 Ma (Jacobs et al. 1999a).

Late Mesoproterozoic rocks are also exposed in the Haag Nunataks (West Antarctica). Geophysical data indicate that the Haag Nunataks, together with the Ellsworth-Whitmore Mountains, form an extensive continental fragment that could have resided within the Natal Embayment (Lawver et al., 1991; Dalziel and Grunow, 1992; Grantham et al., 1997). The main rock type of the small exposures is foliated granodioritic gneiss with calc-alkaline geochemistry, probably representing a volcanic/plutonic island-arc complex (Grantham et al., 1997). The granodiorite gneiss is intruded by two sets of granite sheets, which gave $\mathrm{Rb}-\mathrm{Sr}$ isochron dates of $1176 \pm 76 \mathrm{Ma}$ and $1058 \pm 53 \mathrm{Ma}$ and $1003 \pm 18 \mathrm{Ma}$ respectively (Millar and Pankhurst, 1987). Although these ages have large uncertainties, they can be correlated with similar rocks from the Natal Sector (Mzumbe Terrane) and from western Dronning Maud Land. Thus, it is likely that the Haag Nunataks also formed part of the Kalahari Craton.

\section{Dronning Maud Land, East Antarctica}

The ca. 1.2-1.0 Ma Maud Belt represents the continuation of the Namaqua-Natal Province via the Falkland Island and the Haag Nunataks into western Dronning Maud Land (Antarctica) (e.g. Groenewald et al., 1991; Jacobs et al., 1993; Bauer et al, 2003a). The Maud Belt was widely and intensely overprinted during Pan-African high-grade tectonism along the East AfricanAntarctic Orogen (e.g. Jacobs and Thomas, 2004).

In the westernmost part of Dronning Maud Land (Heimefrontfjella) three distinct discontinuitybound juvenile Mesoproterozoic terranes are recognised (e.g. Jacobs et al. 1996, Bauer et al. 2003a,b). The terranes comprise high grade gneisses and granitoids that have been dated between ca. 1160 and 1070 (Arndt et al., 1991; Jacobs et al., 1996, 1999b; Bauer et al., 2003b). Aeromagnetic studies of the area indicate that this part of the Maud Belt is characterised by elongate, high-amplitude, craton-parallel magnetic anomalies, which perfectly correlate with very similar features in the Namaqua-Natal Province in southern Africa (e.g. Golynsky and Jacobs, 2001). Crust formation was succeeded by high-grade metamorphism between ca. 1090-1060 Ma (Jacobs et al., 2003a).

Further to the NE, in Kirwanveggen and Sverdrupfjella, exposures of high-grade rocks similarly represent juvenile material that probably evolved in island arc settings dated between ca. 1200 and $1050 \mathrm{Ma}$ (e.g. Grantham et al., 1995; Groenewald et al., 1995; Board et al., 2005).

In central Dronning Maud Land (Gjelsvikfjella to Grubergebirge), late Mesoproterozoic basement rocks similar to those of Heimefrontfjella and Sverdrupfjella are exposed, although they are much stronger deformed as a result of Late Neoproterozoic medium to high-grade tectono-metamorphic overprinting during continent-continent collision along the East AfricanAntarctic Orogen. Despite this, SHRIMP zircon studies have allowed resolution of the major components of the Mesoproterozoic history and metavolcanic rocks were dated at ca. $1130 \mathrm{Ma}$, with minimal inheritance up to 1190 Ma being recorded (Jacobs et al., 1998). Initial Nd-isotopic 
data of these rocks indicate again relatively juvenile material with little older crustal involvement. An origin along a major volcanic arc has been suggested for this terrane (e.g. Jacobs et al., 1998; Bauer et al., 2003a,b). Syntectonic granitoid intrusions and high-grade metamorphism were dated at ca. 1080 to $1060 \mathrm{Ma}$ (Jacobs et al., 2003b) and thus correlate well with similar data from western Dronning Maud Land.

The easternmost extent of Mesoproterozoic rocks crop out at Sør Rondane, where two distinct tectono-stratigraphic juvenile terranes are recognised, separated by the Sør Rondane suture (Shiraishi and Kagami, 1992; Shiraishi et al., 1999). U-Pb zircon data from the northern, highgrade terrane give a range of ages from 1100 to $1000 \mathrm{Ma}$ (Grew et al., 1992, Shiraishi et al., 1999). Nd-model ages from mafic granulites and enderbitic gneisses are only slightly older and range from ca. 1300 to $1100 \mathrm{Ma}$, thus indicating the relatively juvenile character of these rocks. The southern terrane is an amphibolite to greenschist facies block made up of tonalitic gneisses with mafic enclaves dated at ca. $980 \mathrm{Ma}$, whose geochemistry indicates that they were probably derived from the subduction of young hot oceanic crust (Ikeda and Shiraishi, 1998), possibly at an active continental margin after Rodinia had amalgamated. There is a general change of protolith ages between central Dronning Maud Land and Sør Rondane. The question is however, whether this reflects the Late Mesoproterozoic accretionary history of successively younger material, or later, Neoproterozoic crustal additions (microcontinents) during Gondwana assembly. Thus, it remains to be tested, whether the southern Sør Rondane is the site of an active continental margin after Rodinia had amalgamated. A Late Neoproterozoic suture zone, that could represent the margin of the Kalahari Craton has not unequivocally been identified in the area and, although a number of possibilities have been discussed (e.g. Shiraishi et al., 1994; Kriegsmann, 1995; Jacobs and Thomas, 1996; Fitzsimons 2000; Kleinschmidt et al., 2002; Jacobs et al., 2003b) no convincing, unequivocal position has been presented at this stage.

\section{Northern Mozambique and Malawi}

The Maud Belt probably continued northwards into north-eastern Mozambique, where a collage of discrete gneiss complexes are dominated by late Mesoproterozoic protolith ages that are comparable with those of Dronning Maud Land (e.g. Pinna et al., 1993; NGU-Nordconsult, 2007, Thomas et al., 2006). Within the southernmost of these, the Nampula Complex, an upper amphibolite facies supracrustal gneiss/migmatite sequence is intruded by various suites of orthogneisses, dated between ca. 1150 - 1000 Ma (Kröner et al., 1997; Jamal and De Wit, 2004, NGU-Nordconsult, 2007). The Nampula Complex is bound to the north by the Lurio Belt, a structure comprising a zone of highly dismembered and deformed Neoproterozoic granulitegrade gneisses of different composition and protolith ages. The significance of the Lurio Belt is controversial. Some authors believe it represents a major suture zone and forms a connection via the Zambezi Belt with the Damara Orogen (e.g. Grantham et al., 2003, 2005). Others suggest it has a less fundamental significance, especially because some of the metamorphic complexes to the north of the Lurio Belt are quite similar to the rocks of the Nampula Province (Bingen et al., 2006; Viola et al., 2006), an because of an apparent decrease in strain along the belt from NE to SW. To the north of the Lurio Belt, a number of metamorphic complexes are juxtaposed along NW-verging Neoproterozoic tectonic contacts and are interpreted as a NWdirected sequence of nappes. Two of the larger complexes, the Marrupa and Unango 
complexes, consist mainly of 1.1-1.0 Ga granitoid gneisses, that represent intrusions into a metasedimentary successions with unknown protolith age (Bingen et al., 2006). These complexes appear to continue northwards for an unknown distance into Tanzania. In northeastern Mozambique (and southern Tanzania), extensive high-grade re-working and crustal accretion during the Neoproterozoic have largely obscured the true extent and nature of the Mesoproterozoic crust. In Malawi, similar orthogneisses with crystallisation ages of ca. 1040$1000 \mathrm{Ma}$ were interpreted to represent a continental-margin-arc (Kröner, 2001).

To summarise the complex and fragmentary evidence of the palaeogeographic situation along the southern and eastern margins of the Kalahari Craton during the Mesoproterozoic, the important point to note is that significant portions of juvenile crust formed between ca. 1.3 and $1.0 \mathrm{Ga}$ along subduction-related magmatic arcs along the southern, south-eastern and eastern margin of Proto-Kalahari, while significant proportions of older (Palaeoproterozoic) material incorporated along the Namaqua Sector in the southwest.

\section{The northern margin: Mesoproterozoic remnants}

Along the current northern margin of the Proto-Kalahari Craton, in Zimbabwe, there are remnants of Mesoproterozoic rocks in complex, deformed terranes within the Neoproterozoic Zambezi Belt. These include ophiolitic rocks (in the Chewore Inliers) dated at ca. $1393 \mathrm{Ma}$ (Oliver et al., 1998) and orthogneisses dated at ca. $1080 \mathrm{Ma}$ (Goscombe et al., 2000). However, Johnson and Oliver (2004) considered that these rocks were accreted to the margin of the (then distant) Congo Craton, and that this part of the northern margin of the Kalahari Craton was a passive margin during the Mesoproterozoic (Fig. 3).

West of the Chewore Inliers, the Choma-Kalomo Block probably represents the exposed part of an extensive northeast-trending Mesoproterozoic orogenic belt along the margin of the ProtoKalahari Craton, continuing possibly into Namibia (Hutchins and Reeves, 1980; Hanson et al., 1988; Steven et al., 2000; Singletary et al., 2003). An amphibolite facies metasedimentary sequence is exposed that is intruded by at least two distinct granitoid generations (Hanson et al., 1988; Bulambo et al., 2004). An older suite of granitic gneisses was dated at ca. 1370-1340 $\mathrm{Ma}$ (U-Pb zircon), whilst a second set of foliated granites gave U-Pb zircon ages ranging from ca. 1100-1075 Ma (Hanson et al., 1988; Bulambo et al., 2004). The Choma-Kalomo Block has undergone polyphase deformation with a dominant north-east trending structural grain. The younger granitoids are regarded as late-tectonic.

The Choma-Kalomo Block underwent intense late-Mesoproterozoic rifting along the northwest Botswana rift (Key and Mapeo, 1999). The belt has been penetrated by boreholes in the Kalahari desert, where amphibolite facies gneisses are intruded by granites, the latter of which were U-Pb zircon-dated at ca. $1108 \mathrm{Ma}$ (Singletary et al., 2003).

The north-western margin of this belt, and thus that of the Kalahari Craton, is defined by the Neoproterozoic Matchless-Rooibok zone, which consists of amphibolites and intercalated granitic gneisses (Singletary et al., 2003). Zircons from the granite gneiss gave an igneous crystallisation age of $716.8 \pm 2.2 \mathrm{Ma}$, which is a minimum estimate for the onset of ocean floor spreading along this part of the Kalahari margin (Singletary et al., 2003).

\section{Late Mesoproterozoic intraplate magmatism}


The Proto-Kalahari Craton was subjected to widespread anorogenic magmatism in the period 1.4 to $1.11 \mathrm{Ga}$, which has recently been reviewed by Hanson et al. (2006). The older magmatism at ca. $1.35 \mathrm{Ga}$ is charaterised by alkaline and cabonatite complexes in the southern part of the craton.

The ca. 1.1 Ga volcanic rocks of the Oppdam and Kwebe formations along the north-western margin of Proto-Kalahari have widespread, voluminous equivalents throughout the craton and are known as the Umkondo lavas in Africa (e.g. Hanson et al., 1998, 2004) and as the Borg lavas in Dronning Maud Land (e.g. Barton and Moyes, 1990). Together, this Large Igneous Province magmatic event is known as the Umkondo Igneous Province, covering at least 2 million $\mathrm{km}^{2}$ (Fig. 4). It is inferred to have resulted from the up-welling of a large mantle plume within a short space of time between ca. 1112 and 1116 Ma. (Hanson et al., 2006).

Summarising, the growth of the Proto-Kalahari Craton during the Mesoproterozoic is recorded by multiple events surrounding the craton and within it: from ca. 1400 to $1000 \mathrm{Ma}$, large amounts of crust were added and the area of the resulting Kalahari Craton had almost doubled in area to ca. 13 million $\mathrm{km}^{2}$.

\section{3) The Mesoproterozoic-Neoproterozoic transition (1000-750 Ma): rifting of Kalahari and Rodinia break-up}

The Kalahari Craton is almost completely surrounded by Neoproterozoic rocks, or the products of Neoproterozoic ("Pan-African") tectonic reworking. Early Neoproterozoic rift-related rocks are well preserved along its north-western, western and southern margins. Rifting was eventually superseded by drifting, and finally by the inversion of the rift basins (Fig. 5). High-grade overprint has obliterated much of the rift-related events along the eastern margin of the Kalahari Craton, along the Late Neoproterozoic/Early Palaeozoic East African-Antarctic Orogen.

\section{The north-western margin (Tsumis, Nosib and Ghanzi groups in Namibia)}

Major uplift occurred along the north-western margin of the Kalahari Craton after the extensive ca. 1.1 Ga magmatic event. Rocks of the predominantly sedimentary Tsumis Group rest on the Meso- to Palaeoproterozoic basement along a regional unconformity, with intracontinental redbed successions developed at the base, along with limited contemporaneous volcanic activity. There is an upward transition into overlying monotonous well-bedded, fine-grained, purplish to greyish sandstone with intercalated red slate more than $4500 \mathrm{~m}$ thick (e.g. Doornpoort Formation). These pass upwards into fluviatile, lacustrine and aeolian clastic sediments (Klein Aub Formation). In Botswana, a similar succession, up to $13500 \mathrm{~m}$ thick (Ghanzi Group), was deposited in a northeast trending, ca. $100 \mathrm{~km}$ wide basin seen in the Ghanzi-Chobe belt. Modie (2000) has correlated these with the Namibian succession.

A second regional unconformity separates the Tsumis Group from overlying sediments of the Nosib Group deposited in braided river systems (Kamtsas Formation) and playas lakes (Duruchaus Formation). The Nosib Group is taken to mark the onset of Neoproterozoic Damara sedimentation although there is no evidence of a major break in the deposition style to the underlying Tsumis Group. Rocks in an apparently similar stratigraphic position have been correlated across the Damara orogen (Porada, 1989). They are believed to have been 
deposited in various grabens and half-grabens in a diachronous rift system that was active from at least 900 to $750 \mathrm{Ma}$. However, Nosib Group rocks deposited into the Sesfontein and northern grabens of the Congo Craton in northern Namibia differ considerably in composition from those deposited onto the Kalahari Craton; here, basal conglomerates and quartzite deposited along active faults are overlain by a succession of alkaline volcanic rocks grouped into the Naauwpoort Formation. Local occurrences of carbonate and dolomite suggest partial submarine deposition. The age of the Naauwpoort volcanic rocks has been determined as $752 \pm 7 \mathrm{Ma}$ (U$\mathrm{Pb}$ SHRIMP zircon, De Kock et al., 2000).

\section{The western and southern margins (Gariep-Saldania belts)}

The Saldania Belt (Hartnady et al., 1985) is a low-grade orogenic belt along the south-western and southern margin of Kalahari that underwent refolding during the Permo-Triassic Cape Fold Belt orogeny (e.g. Rozendaal et al., 1999). It is sporadically exposed in isolated windows, with the main exposures north and east of Cape Town. The Neoproterozoic Malmesbury, Kango, Kaaimans and Gamtoos groups are interpreted as distal facies of rift successions (Rozendaal et al., 1999). Rift sediments are associated with rift volcanics and intrusive intermediate to mafic igneous rocks. Mafic rocks of the Bridgetown Formation might represent Neoproterozoic ocean floor. The protolith of the Bridgetown Formation consists of greenstones with WPB-MORB geochemistry, cherts, graphite schists and dolomites and is intruded by mafic dykes (Slabber and Scheepers, in Rozendaal et al., 1999). This formation is correlated with the Voelvlei metavolcanic greenstones that include altered pillow lavas and volcaniclastics. No robust age constraints are available for these metavolcanics at present, but some of the sedimentary rocks must be latest Neoproterozoic, as suggested by detrital zircon dates of $560 \mathrm{Ma}$ from the Tygerberg Formation of the Malmesbury Group near Cape Town (Armstrong et al., 1998).

The Gariep Belt is a low- to medium-grade Neoproterozoic orogen exposed in a small area on the western side of the Kalahari Craton. It consists of two distinct units, the rift-related eastern Port Nolloth Zone and the oceanic western Marmora Terrane, which together document subsequent Neoproterozoic rifting, drifting and final inversion of the Adamaster Ocean (e.g. Frimmel and Frank, 1998). The 7-12 km thick sequences of the Port Nolloth Zone represent a Neoproterozoic rift succession deposited on Namaquan basement, including rift-related sedimentary rocks, intercalated with bimodal volcanic rocks (Frimmel et al., 1996a). Rifting was also associated with the intrusion of voluminous mafic dykes. The basal quartzites are intruded by the ca. $780 \mathrm{Ma}$ Lekkersing granite, giving a minimum age for the lower Port Nolloth Zone sedimentary rocks (Allsop et al., 1979 in Frimmel and Frank, 1998). A Pb-Pb single zircon age from a felsic volcanic rock gave an age of $741 \pm 6 \mathrm{Ma}$, which was interpreted as a crystallisation age (Frimmel et al., 1996b), therefore giving a good estimate for the onset of rifting of ca. 780$740 \mathrm{Ma}$. All rift-related igneous rocks have a within-plate geochemistry and continental flood basalts are absent, typical for a non-volcanic margin (Frimmel et al., 1996a).

The rift volcanics are overlain by the Kaigas Diamictite, which is correlated with the Sturtian glaciation at ca. 720-700 Ma (Von Veh, 1988; Germs, 1995). In the upper part of this formation, carbonate rocks (Hilda Subgroup) and a second massive diamictite horizon (Numees Formation) are developed (Frimmel et al. 1996b). The second diamictite horizon is correlated with the Varangian glaciation at 590 to $560 \mathrm{Ma}$ (Frimmel and Jiang, 2001). 


\section{The northern margin: relationship between the Kalahari Craton and the Zambezi Belt}

The northern margin of Kalahari, adjacent to the Zambezi Belt, is associated with a narrow, but laterally extensive, suite of syn-tectonic granite gneisses and metarhyolites, emplaced between ca. 880-800 Ma. A number of settings for these rocks have been proposed - either in a compressional regime within the Zambezi Belt (e.g. Hanson et al., 1988), or in an extensional environment. However, Late Neoproterozoic/Early Palaeozoic orogenesis along the Zambezi Belt has largely obliterated the evidence. While a clockwise PT path attaining upper amphibolite facies conditions in the Zambezi Belt argues for crustal thickening due to compressional orogenesis (Munyanyiwa and Blenkinsop, 1994), extensional tectonics and an anti-clockwise PT path are recognised in northwest Zimbabwe and point to extension and rifting (Dirks and Sithole, 1999). The latter is supported by the largely A-type geochemistry of the associated granite gneisses and, in the western part of the Zambezi Belt, an extensive supracrustal sequence of bimodal metavolcanic rocks, overlain by metasandstones, metaconglomerates, pelitic schists and extensive metacarbonates is exposed (Hanson, 2003).

In the Rushinga area, Neoproterozoic metasedimentary rocks are interlayered with felsic gneisses that are interpreted as metavolcanic rocks (Chironga metarhyolites). The latter have an A-type geochemistry and gave a U-Pb zircon date of $795 \pm 2$ Ma (Hargrove et al., 2003). A plutonic equivalent of these metavolcanics is probably represented by the Basal Rushinga Intrusive Complex, that gave a U-Pb zircon date of $805 \pm 11 \mathrm{Ma}$ (Vinyu et al., 1999). Thus, there is some evidence to suggest that the 880 to $800 \mathrm{Ma}$ A-type igneous rocks along the northern margin of Kalahari are indicative of rift tectonics.

\section{The Kalahari Craton as part of Rodinia}

Various positions of the Kalahari Craton within Rodinia have been proposed in the past two decades and there is still no consensus (e.g. Hoffman, 1991; Gose et al., 1997; Dalziel et al., 2000; Hanson et al., 1998; Powell et al., 2001a,b; Jacobs et al., 1996, 1997, 2003a; Collins and Pisarevsky, 2005). The available palaeomagnetic data these reconstructions are in part based on are summarized in Tab. 1. In most reconstructions, the southern and southeastern side of the Kalahari Craton are either placed against E Laurentia (in various configurations) or against Western Australia (Powell and Pisarevsky, 2002; Fitzsimons, 2003; Pisarevsky et al., 2003), though it may transpire that neither is true. There is no reliable indication of what may have lain along the NW flanks of the Kalahari Craton. Available palaeomagnetic data show that between ca. $2100 \mathrm{Ma}$ and $1000 \mathrm{Ma}$, the Kalahari Craton drifted between the equator and $60^{\circ}$. This is shown in Fig. 6 where it is assumed for simplicity that the Kalahari Craton was in the northern hemisphere, though the southern hemisphere would be an equally valid option.

Hoffman (1991), Jacobs et al. (1996, 1997), Hanson et al. (1998, 2004) and Dalziel et al. (2000) showed Kalahari adjacent to SW Laurentia with the Umkondo-Borg lavas and dolerites of Kalahari representing an extension of the coeval Keweenawan mafic province of Laurentia (Hanson et al., 1998, 2004; Dalziel et al., 2000). Dalziel et al. (2000) proposed an elegant model in which the Kalahari Craton was interpreted as an indenter into Laurentia, concordant with the model of Jacobs et al. (1993) that showed the Namaqua-Natal-Maud Belt as the product of continent-arc/continent indentation tectonics (Fig. 2, 3). In the model of Dalziel et al. (2000), the 
Namaqua-Natal-Maud Belt formed the opposing counterpart of the Grenville Orogen in the area of the Llano uplift, whilst the Umkondo-Borg-Keweenawan LIP was interpreted as representing rift-related rocks along structures that formed at a high angle to the combined GrenvilleNamaqua-Natal-Maud Belt. Dalziel et al. (2000) assumed continent-continent collision between 1150-1120 Ma with continued tectonism until ca. $980 \mathrm{Ma}$. The timing of the main collision, however, was challenged by palaeomagnetic data that indicated that Kalahari could not have been attached to Laurentia at $1105 \mathrm{Ma}$ (Powell et al., 2001a). The latter authors showed that there was a latitudinal separation of ca. $30^{\circ}$ between Kalahari and the Llano margin of Laurentia at ca. $1105 \mathrm{Ma}$, and at the same time pointed out that Kalahari could have been rotated by $180^{\circ}$, with the Namaqua-Natal Belt facing outboard.

Jacobs et al. (2003b) pointed out that, from the Namaqua-Natal-Maud perspective, the main collision orogeny is best dated at 1090-1060 Ma. This is ca. $60 \mathrm{Ma}$ younger than the timing proposed by Dalziel et al. (2000). However, should the main collision have occurred at 1090$1060 \mathrm{Ma}$, the palaeomagnetic $30^{\circ}$ latitudinal misfit between Kalahari and Laurentia at $1105 \mathrm{Ma}$ would be consistent with a Kalahari-Laurentia collision. In this case, the older Grenville-age metamorphism in the Llano uplift area could represent an early phase of arc-continent collision rather than the main continent-continent collision associated with final Rodinia assembly. It is thus important to note that the collision phase at 1090-1060 Ma recorded in the NamaquaNatal-Maud Belt is similar in age and character to the Ottawan cycle of the Grenville Orogen, which is interpreted as continent-continent collision of Himalayan-style (e.g. Mezger et al., 1992; McLelland et al., 1996).

Hanson et al. (2004) pointed out that the orientation of Kalahari with the Namaqua-Natal-Maud Belt facing away from the Grenville Orogen at ca. $1105 \mathrm{Ma}$ is strongly supported by the comparison of the palaeomagnetic polarity in Keweenawan and Umkondo igneous rocks. In their opinion, the "reversed" orientation of Kalahari required by the model of Dalziel et al. (2000) is precluded by this analysis. We agree that this is a strong argument in view of available Keweenawan and Umkondo palaeomagnetic data, but it is not absolutely conclusive for the following reasons:

1) Despite that the "normal" polarity is dominant in the upper part of the Keweenawan succession and the "reverse" polarity is dominant in its lower part, there are exceptions, and the possibility that $\sim 90 \%$ of the Umkondo palaeomagnetic ("reverse") sites (Hanson et al., 2004) to be correlative with the upper part of those exceptional cases of the "normal" intervals in the lower Keweenawan is unlikely, but yet possible. Hanson et al. (2004) also mentioned that most of the palaeomagnetically studied Umkondo rocks were emplaced in less than $3 \mathrm{Ma}$, which can explain this possible coincidence. If this is the case, the "reversed" position of Kalahari is justified.

2) Second, if the collision of Kalahari occurred sufficiently after the 1109 Ma Umkondo magmatism, Kalahari could have rotated through 180 degrees and could have collided with Laurentia in a similar fashion as in the model of Dalziel et al. (2000). This scenario may appear overly complex but it cannot be discounted entirely.

3) Third, if the north-western margin of Kalahari was an active continental margin, it could also have been this margin that collided with Laurentia. In this way a large rotation could be avoided and the north-western margin could be the counterpart to the 
Grenville orogen. In this scenario one would need another major continent along the Namaqua-Natal-Maud Belt.

The southern margin of the Namaqua-Natal-Maud Belt is not exposed, but it probably represents a Neoproterozoic rifted margin. In Dronning Maud Land however, the Maud Belt is bound by another crustal block to the south. This block is geophysically distinct (Golynsky and Aleshkova, 1997) and is exposed in the Coats Land Nunatak, where it is overlain by unmetamorphosed volcanic rocks that were zircon-dated at ca. 1112 Ma (Gose et al., 1997). These volcanics probably represent part of the Umkondo-Borg-Keewenawan magmatic province. The Coats Land block clearly forms part of the southern foreland of the Maud Belt and is not part of the belt itself. Gose et al. (1997) suggested that the age of their palaeopole from Coats Land $\left(22.9^{\circ} \mathrm{N}, 80.3^{\circ} \mathrm{E}\right)$ is approximated by the $\mathrm{U}-\mathrm{Pb}$ titanite age of $1106 \pm 3 \mathrm{Ma}$. The Keweenawan R pole $\left(47^{\circ} \mathrm{N}, 211^{\circ} \mathrm{E}\right.$; Green et al., 1987) has a very similar estimated age of 1107 $\mathrm{Ma}$ (Powell et al., 2001a). Palaeomagnetic reconstruction based on these two poles gives two sets of possible positions of Coats Land with respect to Laurentia, depending on the chosen polarity option (Fig. 7). One of these options permits the connection between the two blocks. The palaeopole from the $1108-1112 \mathrm{Ma}$ Umkondo igneous rocks in Kalahari $\left(63.6^{\circ} \mathrm{N}, 36.2^{\circ} \mathrm{E}\right)$, however, rules out the connection with Laurentia at that time in both polarity options (Fig. 8), as was also shown by Powell et al. (2001a,b), and proves that Coats Land had not amalgamated to Kalahari at this time. If the palaeomagnetic data allow Coats Land to be part of Laurentia, then the Coats Land basement could represent an older part of the Grenville Orogen, e.g. Elzeviran crust, that was not reactivated during later continent-continent collision (OttawanNamaqua-Natal-Maud).

Powell et al. (2001b) and Pisarevsky et al. (2003) pointed out that Kalahari could have lain off the western margin of Australia until 800-750 Ma. The problem with this reconstruction is that the eastern, Mozambiquan side of Kalahari would have had to collide obliquely with the western margin of Australia to form the Pinjarra Orogen. The Namaqua-Natal-Maud Belt, however, as the main collision orogen, would have no counterpart (e.g. Jacobs et al., 2003b). Although this reconstruction is palaeomagnetically permissible, one would need another continental block to the south of Kalahari.

A further test of a possible linkage between Kalahari and Western Australia comes from the comparison of the provenance records in metasedimentary rocks from the Maud Belt and the Pinjarra Orogen (Fitzsimons, 2002, 2003). A comparison of SHRIMP U-Pb zircon ages of paragneisses from the Pinjarra Orogen and the Maud Belt indicated that the metasedimentary sequences in both areas have apparently similar detrital age spectra and, besides a number of age groups common to both regions, all show a characteristic lack of a ca. $1500 \mathrm{Ma}$ age population (Fitzsimons, 2002, 2003). Pre- $1130 \mathrm{Ma}$ age populations were interpreted to have been derived largely from the Albany-Fraser Orogen in Australia and the Wilkes Province in the attached Mawson Craton (East Antarctica), whilst the age populations between 1130-1100 are believed to have been derived form the erosion of a magmatic arc that is exposed in the Maud Province. It was therefore concluded that the sedimentary rocks that are contained in the Maud Belt and the Pinjarra Orogen now, were derived from the same source and that therefore Kalahari and Western Australia could have been juxtaposed in Rodinia. However, a large set of new detrital zircon ages (ca. 1000 grains) from the Northampton Complex and the Maud 
Province (Ksienzyk, 2006; and unpubl. data) shows distinctly different detrital age components for the two areas for ages $>1300 \mathrm{Ma}$ and no notable lack of ca. $1500 \mathrm{Ma}$ detrital ages in the Northampton Complex. Fitzsimons $(2002,2003)$ comparisons are based on a limited dataset, so in our view, the detrital zircon record does not support a Kalahari - West Australia connection.

It was argued that Kalahari could have been attached to Western Australia until 800-750 Ma, when it started to rift away (e.g. Pisarevsky et al., 2003). The breakup could have been associated with the Mundine Well dyke swarm in Western Australia (Wingate and Giddings, 2000). Although, a 800-750 Ma rifting event for Kalahari is permissible, the main rift activity along the margin of Kalahari happened along the western margin and not much evidence for rifting along the eastern margin is known, as would be required for the Kalahari-Western Australia model (though the eastern margin is strongly overprinted and therefore rift related rocks might not be preserved).

The proximity of Kalahari to eastern Laurentia at ca. $1000 \mathrm{Ma}$, though permissible by palaeomagnetic data (Powell et al., 2001a), faces some problems. First, in most reconstructions of Rodinia (e.g., Hoffman, 1991; Dalziel, 1997; Pisarevsky et al., 2003; Li et al, this issue) Amazonia and Rio de La Plata are juxtaposed to eastern Laurentia, leaving no space for Kalahari. Second, if connected to eastern Laurentia, Kalahari should have rifted away at the time of the opening of the lapetus (at 600-550 Ma; Cawood and Pisarevsky, 2006), which leaves virtually no time for Kalahari to join the rest of Gondwana at 550-530 Ma (Collins and Pisarevsky, 2005). There is some evidence for ca. $750 \mathrm{Ma}$ rifting in the central part of he Grenville province of Laurentia (e.g. Aleinikoff et al., 1995; Tollo and Aleinikoff, 1996; Tollo et al, 2004), which roughly coincides with the timing of rifting recorded along the margins of Kalahari. However, most workers interpret the ca. 750 rift event along the margin of Laurentia as a failed rift and it is thought that the rift-drift transition here started much later, at 550-530 Ma (e.g. Cawood et al., 2001).

\section{Conclusion}

Over the past two decades there has been much interest and research carried out on the Kalahari Craton, including a wealth of new field observations and high-precision geochronological and geophysical data. This has led to a much better understanding of the geological evolution of various components of the craton. During its evolution the craton initiated as an Archaean nucleus with a surface area of ca. 4,500,000 $\mathrm{km}^{2}$, grew by successive continental accretion and magmatic events to ca. $7,000,000 \mathrm{~km}^{2}$ by the end of the Palaeoproterozoic, to eventually cover an area of over $13,000,000 \mathrm{~km}^{2}$ by the end of the Mesoproterozoic. While the evolution and architecture of the Kalahari Craton is becoming quite well constrained, its place in Rodinia remains poorly understood and there is no real consensus on the position, orientation or identity of any of the crustal blocks which may have been its supercontinental neighbors. In particular, reliable palaeomagnetic data remain sparse, not just for the Kalahari Craton but for many of the fragments of Rodinia with which it may have been juxtaposed. Consequently, while we have some idea of the global position and movements of the Kalahari Craton through time, its relative position in Rodinia remains speculative and there is much potential for further work and interpretation. 
Acknowledgements: This project was supported in part by Deutsche Forschungsgemeinschaft grant Ja 617/23. Jacobs also acknowledges support through a Gledden Fund (University of Western Australia). RJT publishes with the permission of the Executive Director, British Geological Survey. We thank W. Bauer, M. de Wit, I. Dalziel and an anonymous reviewer for their critical and constructive reviews. This is TSRC publication ... and a contribution to IGCP 440 . 


\section{References:}

Adie, R.J., 1952. The position of the Falkland Islands in a reconstruction of Gondwanaland. Geol. Mag. 89, 401-410.

Aleinikoff, J.N., Zartman, R.E., Walter, M., Rankin, D.W., Lyttle, P.T., Burton, W.C., 1995. U-Pb ages of metarhyolites of the Catoctin and Mount Rogers formations, central and southern Appalachians: evidence for two phases of lapetan rifting. Am. J. Sci. 295, 428-454.

Armstrong, R., de Wit, M., Reid, D.L., York, D., Zartman, R., 1998. Cape Town's Table Mountain reveals rapid Pan-African uplift of its basement rocks. J. Afr. Earth Sci. 27, 1A, 10-11.

Arndt, N. T., Todt, W., Chauvel, M., Tapfer, M., Weber, K., 1991. U-Pb zircon age and Nd istopic composition of granitoids, charnockites and supracrustal rocks from Heimefrontfjella, Antarctica. Geol. Rundsch. 80, 759-777.

Barton, J.M., Moyes, A.B., 1990. Cooling patterns in western Dronning Maud Land, Antarctica, and southeastern Africa and their implications to Gondwana. Zentralblatt Geol. Paläontologie, Teil I, $1 / 2,33-43$.

Bates, M.P., Jones, D.L., 1996. A palaeomagnetic investigation of the Mashonaland dolerites, north-east Zimbabwe. Geophys. J. Int. 126, 513-524.

Bauer, W., Thomas, R.J., Jacobs, J., 2003a. Proterozoic-Cambrian history of Dronning Maud Land in the context of Gondwana assembly. Geol. Soc. Lond. Spec. Publ. 206, 247-269.

Bauer, W., Jacobs, J., Fanning, M., Schmidt, R., 2003b. Geochemical constraints for Late Mesoproterozoic arc and back-arc volcanism in the Heimefrontfjella (East Antarctica) and implications for the palaeography at the southeastern margin of the Kaapvaal-Grunehogna Craton. Gond. Res. 6, 449-465.

Becker, T., Hansen, B.T., Weber, K., Wiegand, B., 1996. U-Pb and Rb-Sr isotopic data of the Mooirivier Complex, the Weener Igneous Suite, and the Gaub Valley Formation (Rehoboth Sequence), Nauchas area and their significance for the Paleoproterozoic evolution of Namibia. Communs. Geol. Surv. Namibia 11, 31-46.

Becker, T., Hansen, B.T, Weber K., Wiegand, B., 2004. Isotope systematics (Sm/Nd, Rb/Sr, U/Pb) of the Elim Fm, the Alberta Complex, and the Weener Igneous Complex - probable genetic links between magmatic rocks of the Paleoproterozoic Rehoboth Basement Inlier/Namibia. Comm. Geol. Surv. Namibia 13, 75-84.

Becker, T., Ledru, P., Garoeb, H., Milesi, J.P., 2005. The Mesoproterozoic event within the Rehoboth Basement Inlier of Namibia - review and new aspects of metamorphism, structure and stratigraphical subdivision. S. Afr. J. Geol. 108, 317-344.

Becker, T., Schreiber, U., Kampunzu, A.B., Armstrong, R., 2006. Mesoproterozoic rocks of Namibia and their plate tectonic setting. J. Afr. Earth Sci., in press.

Bingen, B., Viola G., Henderson I.H.C., Smethurst M., Boyd R., Thomas R.J., Bjerkgård T., Feito P., Hollick L.M., Jacobs J., Key R.M., Rossi D., Sandstad J.S., Skår Ø., Solli A., Tveten, E., 2006. Geochronology of Pan-African terrain assembly in the NE Mozambique. 21st Colloquium of African Geology, Maputo, Mozambique. Abstracts, p. 12-14.

Board, W.S., Frimmel, H.E., Armstrong, R.A., 2005. Pan-African tectonism in the western Maud-Belt: P-T-t path for high-grade gneisses in the H.U. Sverdrupfjella, East Antarctica. J. Petrol. 46, 671-699. 
Borg, G., 1988. The Koras-Sinclair-Ghanzi rift in southern Africa: volcanism, sedimentation, age relationships and geophysical signature of a late middle Proterozoic rift system. Precamb. Res. 38, 75-90.

Briden, J.C., Duff, B.A., Kröner, A., 1979. Palaeomagnetism of the Koras Group, Northern Cape Province, South Africa. Precamb. Res. 10, 43-57.

Bulambo, M., De Waele, B., Kampunzu, A.B., Tembo, F., 2004. SHRIMP U-Pb geochronology of the Choma-Kalomo block (Zambia) and geological implications. Abstr. 20th Colloquium of African Geology Orleans, France, p. 26-27.

Burger, A.J., Walraven, F., 1978. Summary of age determinations carried out during the period April 1975 to March 1976. Ann. Geol. Surv. S. Afr. 11, 323-329.

Cawood, P.A., McCausland, P.J.A., Dunning, G.R. 2001. Opening lapetus: constraints from the Laurentian margin in Newfoundland. Geol. Soc. Am. Bull. 113, 443-453.

Cawood, P.A., Pisarevsky, S.A., 2006. Was Baltica right-way-up or upside-down in the Neoproterozoic? J. Geol. Soc., Lond. 163, 753-759.

Cingolani, C.A., Varela, R., 1976. Investigaciones, geologicas y geochronologicas en el extremo sur de la isla Gran Malvina, sector de Cabo Belgrano (Cabo Meredith), Islas Malvinas. Actas del sexto congreso Geologico Argentino, 457-473.

Clifford, T.N., 1970. The structural framework of Africa. In: Clifford, T.N., Gass, I.G. (Eds.): African Magmatism and Tectonics. Oliver and Boyd, Edinburgh, p. 1-26.

Collins, A.S., Pisarevsky, S.A., 2005. Amalgamating eastern Gondwana: The evolution of the CircumIndian Orogens. Earth-Sci. Rev. 71, 229-270.

Colliston, W.P., Praekelt, H.E., Schoch, A.E., 1991. A progressive shear model for the Proterozoic Aggeneys Terrane, Namaqua mobile belt, South Africa. Precamb. Res. 49, 205-215.

Cornell, D.H., Humphreys, H., Theart, H.F.J., Scheepers, D.J., 1992. A collision related pressure temperature time path for Prieska Copper Mine, Namaqua Natal Tectonic Province, South Africa. Precamb. Res. 59, 43-71.

Cornell, D.H., Petterson, A., 2007. Ion probe dating of the Achab Gneiss, a young basement to the Central Bushmannland Ore district. J. Afr. Earth Sci. 47, 112-116.

Corner, B., 1991. Crustal architecture of the Precambrian of the Kaapvaal Province from geophysical data. Terra Abstracts, 3, p. 5.

Dalziel, I.W.D., Grunow, A.M., 1992. Late Gondwanide tectonic rotations within Gondwana: Causes and consequences. Tectonics 11, 603-606.

Dalziel, I.W.D., 1991. Pacific margins of Laurentia and East Antarctica-Australia as a conjugate rift pair: Evidence and implications for an Eocambrian supercontinent. Geology 19, 598-601.

Dalziel, I.W.D., 1997. Neoproterozoic-Paleozoic geography and tectonics: Review, hypothesis, environmental speculation. Geol. Soc. Am. Bull. 109, 16-42.

Dalziel, I.W.D., Mosher, S., Gahagan, L.M., 2000. Laurentia-Kalahari Collision and the Assembly of Rodinia. J. Geol. 108, 499-513.

De Kock, G.S., Eglington, B.M., Armstrong, R.A., Harmer, R.E., Walraven, F., 2000. U-Pb and Pb-Pb ages on the Naauwpoort rhyolite, Kawakeup leptite and Okongava Diorite: implications for the onset of rifting and of orogenesis in the Damara belt, Namibia. Commun. Geol. Surv. Namibia 12, 81-88. 
De Wit, M.J., de Ronde, C.E.J., Tredoux, M., Roering, C., Hart, R.J., Armstrong, R.A., Green, R.W.E., Peberdy, E., Hart, R.A., 1992. Formation of an Archean continent. Nature 357, 553-562.

Dirks, P.H.G.M., Sithole, T.A., 1999. Eclogites in the Makuti gneiss of Zimbabwe: implications for the tectonic evolution of the Zambesi belt in southern Africa. J. Met. Geol. 17, 593-612.

Eglington, B.M., 2006. Evolution of the Namaqua-Natal Belt, southern Africa - A geochronological and isotope geochemical review. J. Afr. Earth Sci. 46, 93-111.

Eglington, B.M., Harmer, R.E. and Kerr, A., 1989. Isotope and geochemical constraints on Proterozoic crustal evolution in south-eastern Africa. Precamb. Res. 45, 159-174.

Eglington, B.M., Armstrong, R.A., 2004. The Kaapvaal Craton and adjacent orogens, Southern Africa: a geochronological database and overview of the geological development of the craton. S. Afr. J. Geol. 107, 13-32.

Evans, D.A.D., Beukes, N.J., Kirschvink, J.L., 2002. Paleomagnetism of a lateritic paleoweathering horizon and overlying Paleoproterozoic red beds from South Africa: Implications for the Kaapvaal apparent polar wander path. J. Geophys. Res. 107(B12), 2326, doi:10.1029/2001JB000432.

Fitzsimons, I.C.W., 2000. Grenville-age basement provinces in East Antarctica: Evindence for three separate collisional orogens. Geology $28,879-882$.

Fitzsimons I.C.W., 2002. Comparison of detrital zircon ages in the Pinjarra Orogen (WA) and Maud Province (Antarctica): evidence for collision of Western Australia with Southern Africa at 1100 Ma. In: Geoscience 2002: Expanding Horizons. Geological Society of Australia, 16th Australian Geological Convention, Abstracts Volume 67, p. 228.

Fitzsimons, I.C.W., 2003. Proterozoic basement provinces of southern and southwestern Australia, and their correlation with Antarctica. In: Yoshida, M., Windley, B.F., Dasgupta, S. (Eds.): Proterozoic East Gondwana: Supercontinent Assembly and Breakup. Geol. Soc. Lond. Spec. Publ. 206, 93130.

Frimmel, H.E., Frank, W., 1998. Neoproterozoic tectono-thermal evolution of the Gariep belt and its basement, Namibia and South Africa. Precamb. Res. 90, 1-28.

Frimmel, H.E., Hartnady, C.J.H., Koller, F., 1996a. Geochemistry and tectonic setting of magmatic units in the Pan-African Gariep belt, Namibia. Chem. Geol. 130, 101-121.

Frimmel, H.E., Klötzli, U.S., Siegfried, P.R., 1996b. New Pb-Pb single zircon age constraints on the timing of Neoproterozoic glaciation and continental break-up in Namibia. J. Geol. 104, 459-469.

Frimmel, H.E., Jiang, S.-Y., 2001. Marine evaporites from an oceanic island in the Neoproterozoic Adamastor ocean. Precamb. Res. 105, 57-71.

Geringer, G.J., Humphreys, H.C., Scheepers, D.J., 1994. Lithostratigraphy, protolithology and tectonic setting of the Areachap Group along the eastern margin of the Namaqua Mobile Belt, South Africa. S. Afr. J. Geol. 97, 78-100.

Germs, G.J.B., 1995. The Neoproterozoic of southwestern Africa, with emphasis on platform stratigraphy and paleontology. Precamb. Res. 73, 137-151.

Golynsky, A.V., Aleshkova, N.D., 1997. Regional magnetic anomalies of the Weddell Sea region and their geological significance. Polarforschung 67, 101-118.

Golynsky, A., Jacobs, J., 2001. Grenville-age versus Pan-African magnetic anomaly imprints in western Dronning Maud Land, East Antarctica. J. Geol. 109, 136-142.

Goscombe, B., Armstrong, R., Barton, J.M., 2000. Geology of the Chewore Inliers, Zimbabwe: constraining the Mesoproterozoic to Palaeozoic evolution of the Zambezi Belt. J. Afr. Earth Sci. 30, 589-627. 
Gose, W.A., Helper, M.A., Connelly, J.N., Hutson, F.E., Dalziel, I.W.D., 1997. Paleomagnetic data and U$\mathrm{Pb}$ isotopic age determinations from Coats Land, Antarctica: Implications for late Proterozoic plate reconstructions. J. Geophys. Res. 102, 7887-7902.

Gose, W.A., Johnston, S.T., Thomas, R.J., 2004. Age of magnetization of Mesoproterozoic rocks from the Natal sector of the Namaqua-Natal belt, South Africa. J. Afr. Earth Sci. 40, 137-145.

Gose, W.A., Hanson, R.E., Dalziel, I.W.D., Pancake, J.A., Seidel, E.K., 2006. Paleomagnetism of the 1.1 Ga Umkondo large igneous province in southern Africa. J. Geophys.Res., 111, B09101, doi:10.1029/2005JB003897.

Grantham, G.H., Jackson, C., Moyes, A.G., Groenewald, P.B., Harris, P.D., Ferrar, G., Krynauw, J.R., 1995. The tectonothermal evolution of the Kirwanveggen-H.U. Sverdrupfjella areas, Dronning Maud Land, Antarctica. Precamb. Res. 75, 200-231.

Grantham, G.H., Storey, B.C., Thomas, R.J., Jacobs, J., 1997. The pre-break-up position of Haag Nunataks within Gondwana: Possible correlations in Natal and Dronning Maud Land. In: Ricci, C.A. (Ed.), The Antarctic Region: Geological evolution and processes, p. 13-20, Terra Antartica Publication, Siena.

Grantham, G.H., Maboko, M., Eglington, B.M., 2003. A review of the evolution of the Mozambique Belt and implications for the amalgamation and dispersal of Rodinia and Gondwana. In: Yoshida, M., Windley, B.F., Dasgupta, S. (Eds.), Proterozoic East Gondwana: Supercontinent Assembly and Breakup. Geol. Soc. Lond. Spec. Pub. 206, 427-463.

Grantham, G.H., Keidan, H., Hokada, T., Ingram, B.A., Macey, P., Shiraishi, K., Kagashima, S., Azevedo, S., 2005. New U-Pb SHRIMP zircon data from NE Mozambique: implications for Mozambique Belt evolution and Gondwana E-W or N-S? Gondwana 12, Mendoza, Abstracts, p. 182.

Green, J.C., Bornhorst, T.J., Chandler, V.W., Mudrey, M.G., Myers, P.E., Pesonen, L.J., Wilband, J.T., 1987. Keweenawan dykes of the Lake Superior region: evidence for evolution of the Middle Proterozoic Midcontinent Rift of North America. In: Halls, H.C., Fahrig, W.F. (Eds.), Mafic Dyke Swarms, Geol. Assoc. Can. Spec. Pap. 34, 289-302.

Grew, E.S., Manton, W.I., Asami, M., Makimoto, H., 1992. Reconnaissance geochronologic data on Proterozoic polymetamorphic rocks of the eastern Sør Rondane Mountains, East Antarctica. In: 6th International Symposium on Antarctic Earth Sciences, p. 184.

Groenewald, P.B., Grantham, G.H., Watkeys, M.K., 1991. Geological evidence for a Proterozoic to Mesozoic link between Dronning Maud Land, Antarctica, and southeastern Africa. J. Geol. Soc. Lond. 148, 1115-1123.

Groenewald, P.B., Moyes, A.B., Grantham, G.H., Krynauw, J.R., 1995. East Antarctic crustal evolution: geological constraints and modelling in western Dronning Maud Land. Precamb. Res. 75, 231251.

Gutzmer, J., Beukes, N.J., Pickard, A., Barley, M.E., 2000. 1170 Ma SHRIMP age for Koras Group bimodal volcanism, Northern Cape province. S. Afr. J. Geol. 103, 32-37.

Hanson, R.E., Wilson, T.J., Brueckner, H.K., Onstott, T.C., Wardlaw, M.S., Johns, C.C., Hardcastle, K.C., 1988. Reconnaissance geochronology, tectono-thermal evolution, and regional significance of the Middle Proterozoic Choma-Kalomo block, southern Zambia. Precamb. Res. 42, 39-61.

Hanson, R.E., Martin, M.W., Bowring, S.A., Munyanyiwa, H., 1998. U-Pb zircon age for the Umkondo dolerites, eastern Zimbabwe: $1.1 \mathrm{Ga}$ large igneous province in southern Africa-East Antarctica and possible Rodinia correlations. Geology 26, 1143-1146. 
Hanson, R.E., 2003. Proterozoic geochronology and tectonic evolution of southern Africa. In: Yoshida, M., Windley, B.F., Dasgupta, S. (Eds.), Proterozoic East Gondwana: Supercontinent Assembly and Breakup. Geol. Soc. Lond. Spec. Publ. 206, 427-463.

Hanson, R.E., Crowley, J.L., Bowring, S.A., Ramezani, J., Gose, W.A., Dalziel, I.W.D., Pancake, J.A., Seidel, E.K., Blenkinsop, T.G., Mukwakwami, J., 2004. Coeval Large-Scale Magmatism in the Kalahari and Laurentian cratons during Rodinia assembly. Science 304, 1126-1129.

Hanson, R.E., Harmer, R.E., Blenkinsop, T.G., Bullen, D.S., Dalziel, I.W.D., Gose, W.A., Hall, R.P., Kampunzu, A.B., Key, R.M., Mukwakwami, J., Munyanyiwa, H., Pancake, J.A., Seidel, E.K., Ward, S.E., 2006. Mesoproterozoic magmatic and tectonic evolution in the Kalahari Craton. J. Afr. Earth Sci. 46, 141-167.

Hargraves, R.B., 1989. Paleomagnetism of Mesozoic kimberlites in Southern Africa and the Cretaceous apparent polar wander curve for Africa. J. Geophys. Res. 94, 1851-1866.

Hargrove, U.S., Hanson, R.E., Martin, M.W., Blenkinsop, T.G., Bowring, S.A., Walker, N., Munyanyiwa, H., 2003. Tectonic evolution of the Zambezi orogenic belt: geochronological, structural, and petrological constraints from northern Zimbabwe. Precamb. Res. 123, 159-186.

Hartnady, C., Joubert, P., Stowe, C., 1985. Proterozoic crustal evolution in southwestern Africa. Episodes 8, 236-244.

Hattingh, P.J., 1986a. The palaeomagnetism of the main zone in the western Bushveld Complex. Earth Planet. Sci. Lett. 79, 441-452.

Hattingh, P.J., 1986b. The paleomagnetism of the main zone of the eastern Bushveld Complex. Tectonophysics 124, 271-295.

Hattingh, P.J., 1986c. The paleomagnetism of the Merensky Reef footwall rocks of the Bushveld Complex. Trans. Geol. Soc. S. Afr. 89, 1-8.

Hattingh, P.J., 1989. Palaeomagnetism of the upper zone of the Bushveld Complex. Tectonophysics 165, 131-142.

Hegenberger, W., Burger, A.J., 1985. The Oorlogsende Porphyry Member, South West Africa/Namibia: its age and regional setting. Communications of the Geological Survey of South West Africa/Namibia 1, 23-29.

Hoal, B., Heaman, L.M., 1995. U-Pb age constraints from the Awasib Mountain area. In: Proterozoic Crustal and Metallogenic Evolution. Communications of the Geological Survey of Namibia 10, 83-92 (special issue).

Hoal, B.G., 1990. The geology and geochemistry of the Proterozoic Awasib Mountain Terrain, Southern Namibia. Mem. Geol. Surv. Namibia 11, 163 pp.

Hoal, B.G., 1993. The Proterozoic Sinclair Sequence in southern Namibia: intracratonic rift or active continental margin setting? Precamb. Res. 63, 143-162.

Hoffman, P.F., 1991. Did the breakout of Laurentia turn Gondwanaland inside out? Science 252, 14091412.

Hutchins, D.G., Reeves, C.V., 1980. Regional geophysical exploration of the Kalahari in Botswana. Tectonophysics 69, 201-220.

Ikeda, Y., Shiraishi, K., 1998. Petrogenesis of the tonalitic rocks from the Sør Rondane mountains, East Antarctica. Polar Geosci. 11, 143-153. 
Jacobs, J., Thomas, R.J., 1996. Pan-African rejuvenation of the $1.1 \mathrm{Ga}$ Natal Metamorphic Province (South Africa). K-Ar muscovite and sphene fission track evidence. J. Geol. Soc. Lond., 153, 971-978.

Jacobs, J., Thomas, R.J., 2004. A Himalayan-type indenter-escape tectonic model for the southern part of the Late Neoproterozoic/Early Paleozoic East African-Antarctic Orogen. Geology 32, 721-724.

Jacobs, J., Thomas, R.J., Weber, K., 1993. Accretion and indentation tectonics at the southern edge of the Kaapvaal craton during Kibaran (Grenville) orogeny. Geology 21, 203-206.

Jacobs, J., Thomas, R. J., 1994. Oblique collision at about $1.1 \mathrm{Ga}$ along the southern margin of the Kaapvaal continent, south-east Africa. Geol. Rundsch. 83, 322-333.

Jacobs, J., Bauer, W., Spaeth, G., Thomas, R.J., Weber, K., 1996. Lithology and structure of the Grenvilleaged $(\sim 1.1 \mathrm{Ga})$ basement of Heimefrontfjella (East Antarctica). Geol. Rundsch. 85, 800-822.

Jacobs, J., Falter, M., Thomas, R.J., Kunz, J., Jeßberger, E., 1997. 40Ar/39Ar age constraints on the structural evolution of the Mesoproterozoic Natal Metamorphic Province, SE Africa. Precamb. Res. 86, 71-92.

Jacobs, J., Fanning, C. M., Henjes-Kunst, F., Olesch, M., Paech, H.-J., 1998. Continuation of the Mozambique Belt into East Antarctica: Grenville-age metamorphism and polyphase Pan-African high-grade events in central Dronning Maud Land. J. Geol. 106, 385-406.

Jacobs, J., Thomas, R. J., Armstrong, R. A., Henjes-Kunst, F., 1999a. Age and thermal evolution of the Mesoproterozoic Cape Meredith Complex, West Falkland. J. Geol. Soc. Lond. 156, 917-928.

Jacobs, J., Hansen, B.T., Henjes-Kunst, F., Thomas, R.J., Weber, K., Armstrong, R.A., Cornell, D.H., 1999b. New age constraints on the Proterozoic/Lower Paleozoic evolution of Heimefrontfjella, East Antarctica, and its bearing on Rodinia/Gondwana correlations. Terra Antartica 6, 377-389.

Jacobs, J., Fanning, C.M., Bauer, W., 2003a. Timing of Grenville-age vs. Pan-African medium- to high grade metamorphism in western Dronning Maud Land (East Antarctica) and significance for correlations in Rodinia and Gondwana. Precamb. Res. 125, 1-20.

Jacobs, J., Bauer, W., Fanning, C.M., 2003b. New age constraints for Grenville-age metamorphism in western central Dronning Maud Land (East Antarctica), and implications for the palaeogeography of Kalahari in Rodinia. Int. J. of Earth Sci. 92, 301-315.

Jamal, D., De Wit, M.J., 2004. U-Pb geochronology and Sm-Nd data from Lurio Belt, NE Mozambique; significance for crustal evolution. 20th Colloquium of African Geology. BRGM, Orléans, France, 2-7 june 2004, p. 204.

Johnson, S.P., Oliver, G.J.H., 2004. Tectonothermal history of the Kaourerea Arc, northern Zimbabwe: implications for the tectonic evolution of the Irumide and Zambezi Belts of south central Africa. Precamb. Res. 130, 71-97.

Jones, D.L., McElhinny, M.W., 1966. Paleomagmetic correlations of basic intrusions in the Precambrian of southern Africa. J. Geophys. Res. 71, 543-552.

Jones, D.L., Robertson, I.D.M., McFadden, P.L., 1976. A palaeomagnetic study of Precambrian dyke swarms associated with the Great Dyke of Rhodesia. Trans. Geol. Soc. S. Afr. 78, 57-65.

Jones, D.L., Bates, M.P., Li, Z.X., Corner, B., Hodgkinson, G., 2003. Paleomagnetic results from the ca. $1130 \mathrm{Ma}$ Borgmassivet intrusions in the Ahlmannryggen region of Dronning Maud Land, Antarctica, and tectonic implications. Tectonophysics 375, 247-260.

Key, R.M., Mapeo, R., 1999. The Mesoproterozoic history of Botswana and the relationship of the NW Botswana Rift of Rodinia. Episodes 22, 118-122. 
Kleinschmidt, G., Buggisch, W., Läufer, A.L., Helferich, S., Tessensohn, F., 2002. The „Ross orogenic“ structures in the Shackleton Range and their meaning for Antarctica. In: Gamble, J. A., Skinner, D. N. B., Henrys, S. (Eds.): Antarctica at the close of a millennium. Proceedings of the 8th International Symposium on Antarctic Earth Sciences. Royal Society of New Zealand Bulletin $35,75-83$.

Kriegsman, L.M., 1995. The Pan-African event in East Antarctica: a view from Sri Lanka and the Mozambique Belt. Precamb. Res. 75, 263-279.

Kröner, A., 2001. The Mozambique belt of East Africa and Madagascar: significance of zircon and Nd model ages for Rodinia and Gondwana supercontinent formation and dispersal. S. Afr. J. Geol. 105, 151-167.

Kröner, A., Sacchi, R., Jaeckel, P., Costa, M., 1997. Kibaran magmatism and Pan-African granulite metamorphism in northern Mozambique: single zircon ages and regional implications. J. Afr. Earth Sci. 25, 467-484.

Ksienzyk, A., 2006. Detrital zircon ages of metasedimentary rocks from the Northampton Complex, Western Australia. Unpubl. Diploma Thesis, Bremen, 87 p.

Lawver, L.A., Sandwell, D.A., Royer, J.Y., Scotese, C.R., 1991. Evolution of the Antarctic continental margin. In: Thompson, M.R.A., Crame, J.A., Thomson, J.W. (Eds.), Geological Evolution of Antarctica, Cambridge University Press, New York, p. 533-540.

Li, Z.X., Bogdanova, S.V, Collins, A., Davidson, A., Ernst, R.E., Fitzsimons, I.C.W., Fuck, R.A., Gladkochub, D.P., Jacobs, J., Karlstrom, K.E., Lu, S., Milesi, J.-P., Myers, J.S., Natapov, L.M., Pandit, M.K., Pease, V.L., Pisarevsky, S.A., Thrane, K., Vernikovsky, V., De Waele, B., 2007. Assembly, configuration, and break-up history of Rodinia - A synthesis. Precamb. Res., this volume.

Master, S., 1991. Stratigraphy, tectonic setting, and mineralization of the Early Proterozoic Magondi Supergroup, Zimbabwe: a review. University of the Witwatersrand, Economic Geology Research Unit, Information Circular 238.

Martin, A. K., Harnady, C. J. H., 1986. Plate tectonic development of the south-west Indian Ocean: a revised reconstruction of East Antarctica and Africa. J. Geophy. Res. 91, 4767-4786.

Mason, R., 1998. Tectonic setting of the Kalahari suture zone - Botswana. In: McMullan, S., Paya, B., Holmes, H. (Eds.), Abstracts, International Conference on the Role of a National Geological Survey in Sustainable Development. Geological Survey of Botswana, Gaborone, p. 51-53.

McCourt, S., Armstrong, R.A., Grantham, G.H., Thomas, R.J., 2006. Geology and evolution of the Natal Belt, South Africa. J. Afr. Earth Sci., in press, doi:10.1016/j.jafrearsci.2006.01.013

McLelland, J., Daly, J. S., McLelland, J. M., 1996. The Grenville Cycle (ca. 1350-1000 Ma): an Adirondack perspective. Tectonophysics $265,1-28$.

Mezger, K., van der Pluijm, B.A., Essene, E.J., Halliday, A.N., 1992. The Carthage-Colton mylonite zone (Adirondack Mts.) the site of a cryptic suture in the Grenville Orogen? J. Geol. 100, 630-638.

Millar, I.L., Pankhurst, R.J., 1987. Rb-Sr geochronology of the region between the Antarctic Pensinsula and the Transantarctic Mountains: Haag Nunataks and Mesozoic Granitoids. In: Mackenzie, G. (Ed.): Gondwana Six: Structure, Tectonics and Geophysics, American Geophysical Union, Geophysical Monographs, 151-160.

Mitchell, C., Taylor, G.K., Cox, K.G., Shaw, J., 1986. Are the Falkland Islands a rotated microplate? Nature 319, 131-134. 
Moen, H.F.G., 1999. The Kheis Tectonic Subprovince, southern Africa: a lithostratigraphic perspective. S. Afr. J. Geol. 102, 27-42.

Modie, B.N., 2000. Geology and mineralisation in the Meso- to Neoproterozoic Ghanzi-Chobe Belt of northwest Botswana. J. Afri. Earth Sci. 30, 467-474.

Morgan, G.E., 1985. The paleomagnetism and cooling history of metamorphic and igneous rocks from the Limpopo Belt, southern Africa. Geol. Soc. Amer. Bull. 96, 663-675.

Morgan, G.E., Briden, J.C., 1981. Aspects of Precambrian palaeomagnetism, with new data from the Limpopo Mobile Belt and Kaapvaal craton in Southern Africa. Phys. Earth Planet. Interiors 24, 142-168.

Munyanyiwa, H., Blenkinsop, T.G., 1994. Pan-African structures and metamorphism in the Makuti Group, north-west Zimbabwe. J. Afr. Earth Sci 19, 185-198.

Munyanyiwa, H., Kröner, A., Jaeckel, P., 1995. U-Pb and Pb-Pb single zircon ages for charno-enderbites from the Magondi mobile belt, northwest Zimbabwe. S. Afr. J. Geol. 98, 52-57.

Nagel, R., Warkus, F., Becker, T., Hansen, B.T., 1996. U-Pb-Zirkondatierungen der Gaub Valley Formation am Südrand des Damara Orogens-Namibia und ihre Bedeutung für die Entwicklung des Rehoboth Basement Inlier. Zt. Geol. Wiss. 24, 611-618.

Nordconsult-Consortium, 2007. Mineral resources management capacity building project, Republic of Mozambique, Component 2: Geological infrastructure development project, Geological Mapping Lot 1, Report No. B6.f. Sheet explanation. Unpublished report, 778 pp. + annexes.

Oliver, G.J.H., Johnson, S.P., Williams, I.S., Herd, D.A., 1998. Relict 1.4 Ga oceanic crust in the Zambezi Valley, northern Zimbabwe: evidence for Mesoproterozoic supercontinental fragmentation. Geology 26, 571-573.

Onstott, T.C., Hargraves, R.B., Joubert, P., 1986. Constraints on the tectonic evolution of the Namaqua Province II: Reconnaissance palaeomagnetic and 40Ar/39Ar results from the Namaqua Province and the Kheis Belt. Trans. Geol. Soc. S. Afr. 89, 143-170.

Peters, M., Haverkamp, B., Emmermann, R., Kohen, H., Weber, K., 1991. Palaeomagnetism, K-Ar dating and geodynamic setting of igneous rocks in western and central Neuschwabenland, Antarctica. In: Thompson, M.R.A., Crame, J.A., Thompson, J.W. (Eds.), Geological evolution of Antarctica, Cambridge University Press, Cambridge, p. 549-555.

Pfurr, N., Ahrendt, H., Hansen, B.T., Weber, K., 1991. U-Pb and Rb-Sr isotopic study of granitic gneisses and associated metavolcanic rocks from the Rostock massifs, southern margin of the Damara Orogen: implications for lithostratigraphy of this crustal segment. Communications of the Geological Survey of Namibia 7, 35-48.

Pinna, P., Jourde, G., Caluez, J.-Y., Mroz, J. P., Marques, J. M., 1993. The Mozambique Belt in northern Mozambique: Neoproterozoic (1100-850 Ma) crustal growth and tectogenesis and superimposed Pan-African (800-550 Ma) tectonism. Precamb. Res. 62, 1-59.

Pisarevsky, S.A., Wingate, M.T.D., Powell, C.McA., Johnson, S., Evans, D.A.D., 2003. Models of Rodinia assembly and fragmentation. In: Yoshida, M., Windley, B.F., Dasgupta, S. (Eds.): Proterozoic East Gondwana: Supercontinent Assembly and Breakup. Geol. Soc. Lond., Spec. Publ. 206, 35-55.

Porada, H., 1989. Pan-African rifting and orogenesis in southern to equatorial Africa and eastern Brazil. Precamb. Res. 44, 103-136. 
Powell, C.M., Pisarevsky, S.A., 2002. Late Neoproterozoic assembly of East Gondwana. Geology 30, 36.

Powell, C.McA., Jones, D.L., Pisarevsky, S.A., Wingate, M.T.D., 2001a. Paleomagnetic constraints on the position of the Kalahari craton in Rodinia. Precamb. Res. 110, 33-46.

Powell, C.McA, Pisarevsky, S.A., Wingate, M.T.D., 2001b. A new shape for Rodinia. Gond. Res. 4, 736737.

Ramokate, L-V., Mapeo, R.B.M., Corfu, R., Kampunzu, A.B., 2000. Proterozoic geology and regional correlation of the Ghanzi-Makunda area, western Botswana. J. Afr. Earth Sci 30, 443-466.

Reid, D.L., 1997. Sm-Nd age and REE geochemistry of Proterozoic arc-related igneous rocks in the Richtersveld Subprovince, Namaqua Mobile Belt, southern Africa. J. Afr. Earth Sci. 24, 621633.

Reid, D.L., Welke, H.J., Erlank, A.J., Moyes, A.B., 1987. The Orange River Group: a major Proterozoic calcalkaline volcanic belt in the western Namaqua Province, southern Africa. In: Pharoah, T.C., Beckinsale, R.D., Richard, D. (Eds.), Geochemistry and mineralization of Proterozoic volcanic suites., Geol. Soc. Spec. Publ., 327-346.

Robb, L.J., Armstrong, R.A., Waters, D.J., 1999. The history of granulite-facies metamorphism and crustal growth from single zircon U-Pb geochronology, Namaqualand, South Africa. J. Petrology 40, 1747-1770.

Rozendaal, A., Gresse, P.G., Scheepers, R., Le Roux, J.P., 1999. Neoproterozoic to Early Cambrian crustal evolution of the Pan-African Saldania Belt, South Africa. Precamb. Res. 97, 303-323.

Schneider, T., Becker, T., Borg, G., Hilken, U., Weber, K., 2004. New U- Pb zircon ages of the Nuckopf Formation and their significance for the Mesoproterozoic event in Namibia. Communications of the Geological Survey of Namibia 13, 63-74.

Schwartz, M.O., Kwok, Y.Y., Davis, D.W., Akanyang, P., 1996. Geology, geochronology and regional correlation of the Ghanzi Ridge, Botswana. S. Afr. J. Geol. 99, 245-250.

Shiraishi, K., Kagami, H., 1992. Sm-Nd and Rb-Sr ages of metamorphic rocks from the Sør Rondane Mountains, East Antarctica. In: Yoshida, Y., Kaminuma, K., Shiraishi, K. (Eds.), Recent Progress in Antarctic Earth Science, Terrapub, Tokyo, p. 29-35.

Shiraishi, K., Ellis, D. J., Hiroi, Y., Fanning, C. M., Motoyoshi, Y., Nakai, Y., 1994. Cambrian orogenic belt in east Antarctica and Sri Lanka: Implications for Gondwana assembly. J. Geol. 102, 47-65.

Shiraishi, K., Fanning, C.M., Armstrong, R., Motoyoshi, Y., 1999. New evidence for polymetamorphic events in the Sør Rondane Mountains, East Antarctica. $8^{\text {th }}$ Int. Sym. Ant. Earth Sci., Wellington, Abstract Vol., p. 280.

Singletary, S., Hanson, R.E., Martin, M.W., Ramokate, L.V., Direng, B.B., Krol, M.A., 2003. Geochronology of basement rocks in the Kalahari Desert, Botswana, and implications for regional Proterozoic tectonics. Precamb. Res. 121, 47-71.

Steven, N., Armstrong, R., Smalley, T., Moore, J., 2000. First geological description of a Late Proterozoic (Kibaran) metabasaltic andesite-hosted chalcocite deposit at Omitiomire, Namibia. In: Cluer, J.K., Price, J.G., Struhsacker, E.M., Hardyman, R.F., Morris, C.L. (Eds.), Geology and Ore Deposits 2000: The Great Basin and Beyond. Geological Society of Nevada Symposium Proceedings, 711-734.

Thomas, R. J., 1989. A tale of two tectonic terranes. S. Afr. J. Geol. 92, 306-321. 
Thomas, R. J., Eglington, B. M., Bowing, S. A., Retief, E. A., Walraven, F., 1993. New isotope data from a Late Proterozoic porphyritic granite-charnockite association from Natal, South Africa. Precamb. Res. 61, 83-101.

Thomas, R.J., Agenbacht, A.L.D., Cornell, D.H., Moore, J.M., 1994. The Kibaran of southern Africa: tectonic evolution and metallogeny. Ore Geol. Rev. 9, 131-160.

Thomas, R. J., Jacobs, J., Weber, K., 1997. Geology of the Mesoproterozoic Cape Meredith Complex, West Falkland. In: Ricci, C.A. (Ed.), The Antarctic Region: Geological evolution and processes. Terra Antartica Publication, Siena, 21-30.

Thomas, R.J., Bauer, W., Bingen, B., de Azevedo, de Sousa Soares, H., Hollick, L., Feitio, P., Fumo, C., Gonzales, E., Jacobs, J., Manhica, V., Manuel, S., Matuza, G., Tembe, D., Uachave, B. and Viola, G., 2006. Mozambique Belt in the Milanje-Mocuba-Malema area, Mozambique. Geochronology of Pan-African terrain assembly in the NE Mozambique. 21st Collquium of African Geology, Maputo, Mozambique. Abstracts, 161-163.

Tollo, R.P., Aleinikoff, J.N., 1996. Petrology and U-Pb geochronology of the Robertson River igneous suite, Blue Ridge Province, Virginia - evidence for multistage magmatism associated with the early episode of Laurentian rifting. Am. J. Sci. 296, 1045-1090.

Tollo, R.P., Aleinikoff, J.N., Batholomew, M.J., Rankin, D.W., 2004. Neoproterozoic A-type granitoids of the central and southern Appalachians: intraplate magmatism associated with episodic rifting of the Rodinian supercontinent. Precamb. Res. 128, 3-38.

Van Bever Donker, J., 1991. A synthesis of the structural geology of a major tectonic boundary between a 1000 m.y. mobile belt and a 3000 m.y. craton. Tectonophysics 196, 359-370.

Van der Voo, R., 1990. The reliability of paleomagnetic data. Tectonophysics 184, 1-9.

Vinyu, M.L., Hanson, R.E., Martin, M.W., Bowring, S., Jelsma, H.A., Krol, M.A., Dirks, P.H.G.M., 1999. U$\mathrm{Pb}$ and 40Ar/39Ar geochronological constraints on the tectonic evolution of the easternmost part of the Zambezi orogenic belt, northeast Zimbabwe. Precamb. Res. 98, 67-82.

Viola, G., Henderson, I., Bingen, B., Feitio, P., Thomas, R., Hollick, L., Jacobs, J., 2006. A new tectonic framework for northern Mozambique. 21st Collquium of African Geology, Maputo, Mozambique. Abstracts, 168-170.

Von Veh, M.W., 1988. The stratigraphy and structural evolution of the Late Proterozoic Gariep group in the Sendelingsdrif-Annisfontein area, northwest Cape Province. unpublished PhD thesis Univ. Cape Town 174 pp.

Watters, B.R., 1974. Stratigraphy, igneous petrology and evolution of the Sinclair Group in southern SWA. Bulletin of the Precambrian Research Unit, University of Cape Town 16, 235 pp.

Wingate, M.T.D., Giddings, J.W., 2000. Age and palaeomagnetism of the Mundine Well dyke swarm, Western Australia: implications for an Australia-Laurentia connection at $755 \mathrm{Ma}$. Precamb. Res. 100, 335-357. 


\section{Figure Captions}

Fig. 1: Components of the Archaean to Palaeoproterozoic core of Kalahari within a Gondwana reconstruction. Mesoproterozoic crustal additions are indicatEd. Kalahari is completely surrounded by Late Neoproterozoic/Early Palaeozoic mobile belt, including the Damara and Gariep-Saldania belts, the East African-Antarctic Orogen and the Zambesi Belt. The boundary of major Neoproterozoic to Cambrian (Pan-African) overprint is indicated as a blue dashed line. The original extent of Kalahari is difficult to estimate due to the extensive overprint along its margins. Hints for original boundaries are provided by suture zones that are locally preserved. African geology adapted from Singletary et al. (2003).

Fig. 2: Palaeogeographic reconstruction of Proto-Kalahari at ca. $1750 \mathrm{Ma}$. The Palaeoproterozoic is characterized by long-lasting crustal accretion along the northwestern margin of the Archaean Zimbabwe-Kaapvaal-Grunehogna Craton, which led to the addition of the Kheis-Okwa-Magondi Belt. Abbreviations: G - Grunehogna Craton, K - Kaapvaal Craton, LIM - Limpopo Belt, R - Rehoboth, Ri - Richtersveld, Z - Zimbabwe Craton.

Fig. 3: By $1200 \mathrm{Ma}$, Proto-Kalahari was surrounded by active continental margins and island arc terranes that later started to accrete. The main convergence direction (large arrow) was directed towards the south-west. A passive margin might have existed along the northern margin of Proto-Kalahari (e.g. Johnson and Oliver, 2004). Abbreviation: G - Grunehogna Craton, DML - Dronning Maud Land, K - Kaapvaal Craton, Moz - northern Mozambique, R Rehoboth, S - Sinclair, Z - Zimbabwe Craton. Black triangles refer to Mesoproterozoic intraplate alkaline to carbonatite intrusions at ca. $1300 \mathrm{Ma}$ (after Hanson et al., 2006).

Fig. 4: By $1080 \mathrm{Ma}$, the active northwestern margin had stopped, the Umkondo-Kwebe-Borg large igneous province had been emplaced and collision and indentation tectonic processes (big arrow) were continuing along the southern margin of Kalahari. Whilst large amounts of juvenile crust had accreted along the SE, E and NW margin, major components of older crust were accreted along the Namaqua Belt. Abbreviation: A - Areachap terrane, BL - Bushmanland Terrane, CKB - Choma-Kaloma Block, FI - Falkland Islands, G - Grunehogna Craton, DML Dronning Maud Land, H - Haag Nunatak, K - Kaapvaal Craton, L - Lurio Belt, MMU - MarupaMalawi-Unango terrane, NAM - Nampula Province, S - Sinclair, SR - Sør Rondane, R Rehoboth, Ri - Richtersveld, Z - Zimbabwe Craton.

Fig. 5: By $\mathbf{7 0 0}$ Ma, Kalahari had rifted from Rodinia. The rift history is best preserved along the western margin of Kalahari. A piece of the colliding counterpart of Kalahari (Laurentia?, Australia?) remained attached and is now possibly preserved in Coats Land (East Antarctica). Abbreviation: CKB - Choma Kaloma Block, FI - Falkland Islands, $\mathrm{H}$ - Haag Nunatak, L - Lurio 
Belt, MMU - Marupa-Malawi-Unango terrane, NAM - Nampula Province, S - Sinclair, Ri Richtersveld.

Fig. 6: The palaeoposition and growth from the Zimbabwe-Kaapvaal-Grunehogna Craton to Greater Kalahari between ca. 2100 and $1000 \mathrm{Ma}$ is illustrated in 13 steps, based on the palaeomagnetic data presented in Tab.1. New additions of crustal material and active continental margins are indicated in red. For clearer presentation, the size of the continent was enlarged by $50 \%$ and therefore does not represent the real size with respect to the latitudes. Abbreviations: Re - Rehoboth basement; Ma - Kheis-Okwa-Magondi Belt; Ri - Richtersveld microcontinent; $\mathrm{Si}$ - Sinclair active margin.

Fig. 7: Palaeomagnetic reconstruction of Coats Land with respect to Laurentia based on the Coats Land pole (Gose et al., 1997) and the ca.1107 Ma Keweenawan R pole of Laurentia (Green et al., 1987). The reconstruction gives two sets of possible positions of Coats Land with respect to Laurentia, depending on the chosen polarity option. One of these options permits the connection of the two blocks and possibly, Coats Land could represent an older, inboard part of the Grenville Orogen, e.g. Elzeviran crust. The red margin of Coats Land indicates the bounding margin with the Natal-Maud Belt.

Fig. 8: Palaeomagnetic reconstruction of Kalahari with respect to Laurentia at ca. $1107 \mathrm{Ma}$. The palaeopole from the 1108-1112 Ma Umkondo igneous rocks in Kalahari $\left(63.6^{\circ} \mathrm{N}, 36.2^{\circ} \mathrm{E}\right)$, does not permit a connection with Laurentia at this time in both polarity options, as was also shown by Powell et al. (2001a), and clearly proves that Coats Land had not amalgamated to Kalahari at this time. However, since the main collision between Kalahari and Laurentia happened between 1090-1060 Ma, there is enough time to close the space between Kalahari and Laurentia during 1110-1090 Ma. 
Table 1. Palaeomagnetic poles for Kalahari.

\begin{tabular}{|c|c|c|c|c|c|c|c|}
\hline \# & Name & Age (Ma) & $\begin{array}{l}\text { Plat } \\
\left({ }^{\circ}\right)\end{array}$ & $\begin{array}{l}\text { Plong } \\
\left({ }^{\circ}\right)\end{array}$ & $\begin{array}{l}\mathrm{dp} \\
\left({ }^{\circ}\right)\end{array}$ & $\begin{array}{l}\mathrm{dm} \\
\left({ }^{\circ}\right)\end{array}$ & Reference \\
\hline 1 & Port Edward Pluton & $1002-1005$ & $\begin{array}{ll}-7.4 \\
\end{array}$ & 327.8 & 4.2 & 4.2 & Gose et al. 2004 \\
\hline 2 & Central Namaqua & $1000-1030$ & 7.6 & 330.1 & 10.0 & 10.0 & $\begin{array}{l}\text { Onstott et al., 1986; } \\
\text { Robb et al., } 1999\end{array}$ \\
\hline 3 & Kalkpunt Formation & $\sim 1065$ & 57.0 & 3.0 & 4.0 & 7.0 & $\begin{array}{l}\text { Briden et al., 1979; } \\
\text { Onstott et al., } 1986\end{array}$ \\
\hline 4 & Umkondo Province & $1090-1107$ & 66.0 & 37.0 & 3.0 & 3.0 & Powell et al., 2001 \\
\hline 5 & Timbavati Gabbros & $1103-1107$ & 63.2 & 46.8 & 3.3 & 3.3 & Hargraves et al., 1994 \\
\hline 6 & $\begin{array}{l}\text { Borgmassivet Intrusions } \\
\text { (rotated to Kalahari) }\end{array}$ & $1120-1140$ & 64.3 & 38.8 & 3.3 & 3.3 & Jones et al., 2003 \\
\hline 7 & $\begin{array}{l}\text { Premier Kimberlites } \\
\text { (combined) }\end{array}$ & $1155-1175$ & 41.0 & 55.0 & 16.0 & 16.0 & Powell et al., 2001 \\
\hline 8 & Van Dyk Mine Dyke & $1560-1610$ & 12.4 & 13.9 & 6.4 & 7.7 & $\begin{array}{l}\text { Jones and McElhinny, } \\
1966\end{array}$ \\
\hline 9 & Bathlaros Kimberlite & $1600-1700$ & 30.0 & 8.2 & 8.9 & 8.9 & Hargraves, 1989 \\
\hline 10 & Mashonaland Dolerites & $1750-1790$ & 8.0 & 338.0 & 5.0 & 5.0 & Bates and Jones, 1996 \\
\hline 11 & Waterberg sediments & $1720-1860$ & 16.0 & 35.0 & 11.2 & 13.7 & $\begin{array}{l}\text { Morgan and Briden, } \\
1981\end{array}$ \\
\hline 12 & Sebanga Poort dyke & $1800-1850$ & 22.9 & 2.5 & 8.0 & 8.0 & Jones et al., 1976 \\
\hline 13 & Sand River dykes & $1808-1944$ & 2.5 & 9.2 & 9.6 & 10.7 & Morgan, 1985 \\
\hline 14 & Hartley Lava & 1924-1932 & 12.5 & 332.8 & 16.0 & 16.0 & Evans et al., 2002 \\
\hline 15 & $\begin{array}{l}\text { Bushveldt Complex } \\
\text { (combined) }\end{array}$ & $2038-2062$ & 21.3 & 34.0 & 12.9 & 12.9 & $\begin{array}{l}\text { Hattingh, 1986abc, } \\
1989\end{array}$ \\
\hline
\end{tabular}




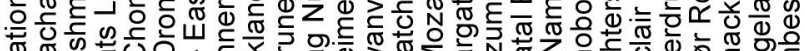

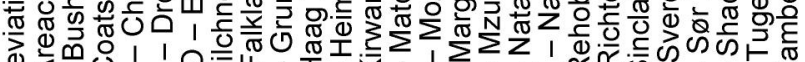

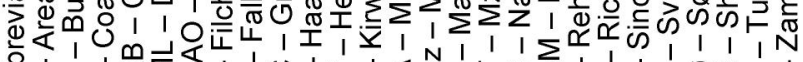

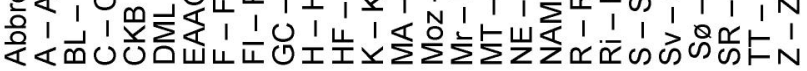
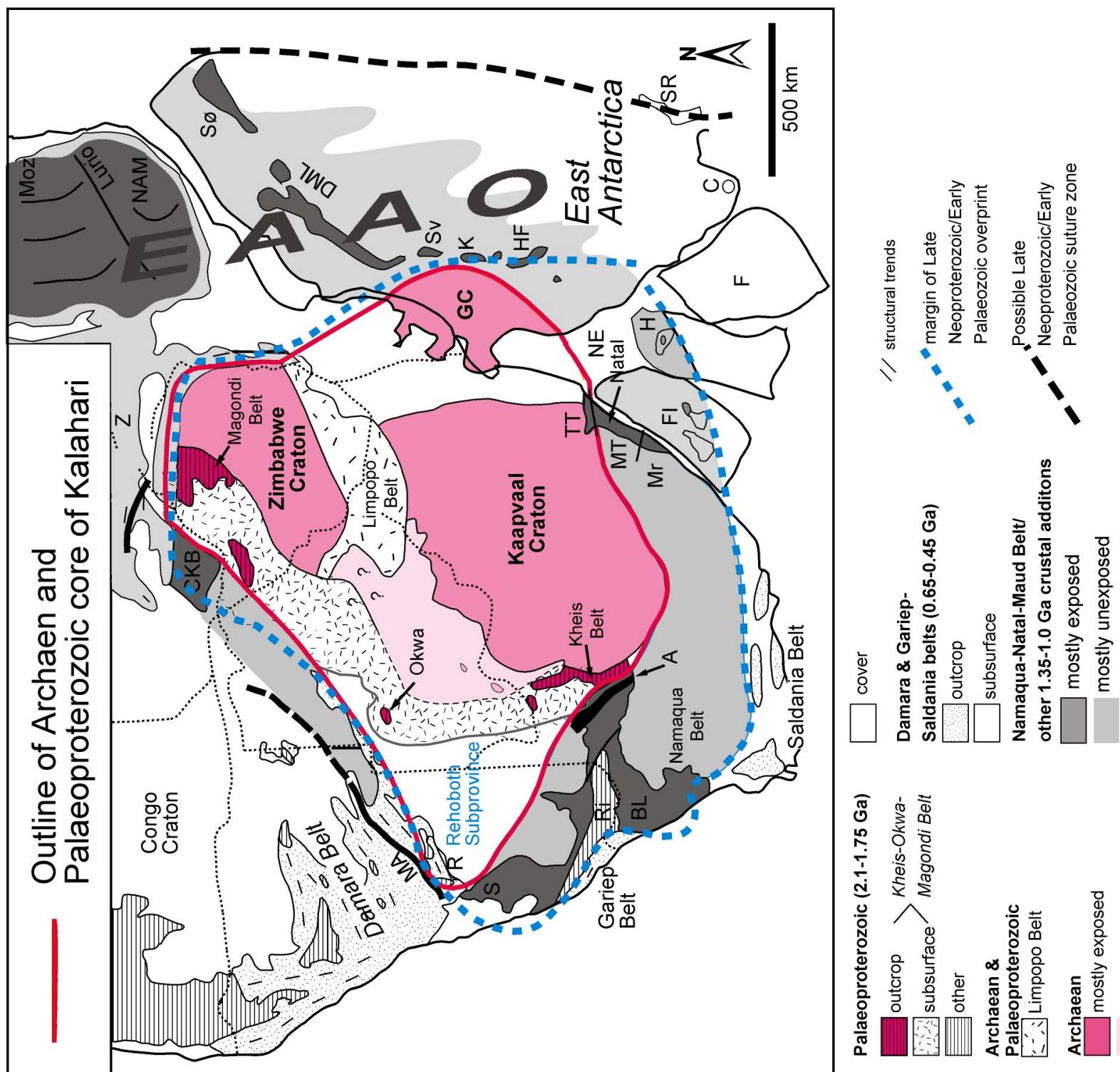
Fig. 2: Jacobs et al.

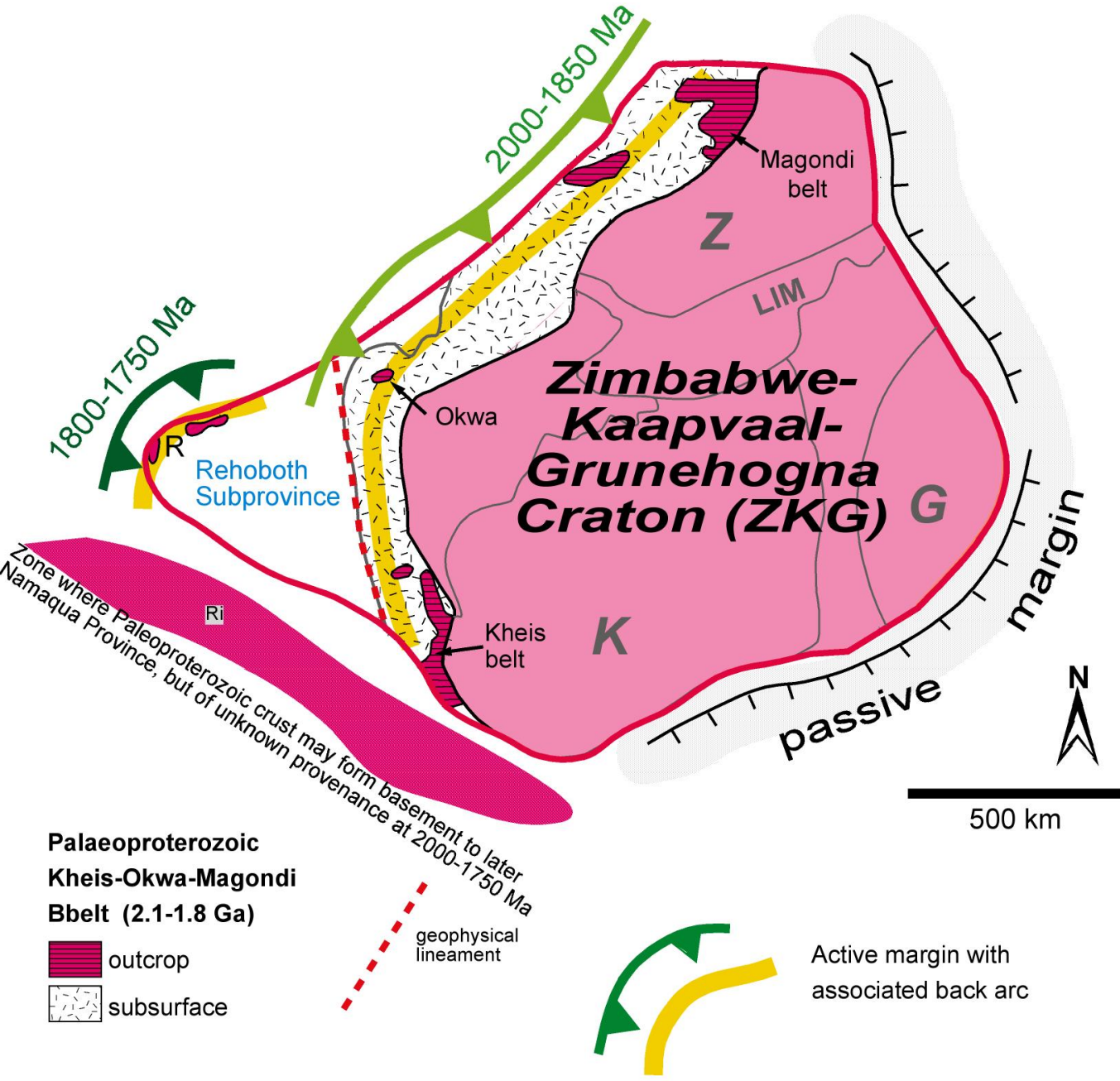


Fig. 3: Jacobs et al.

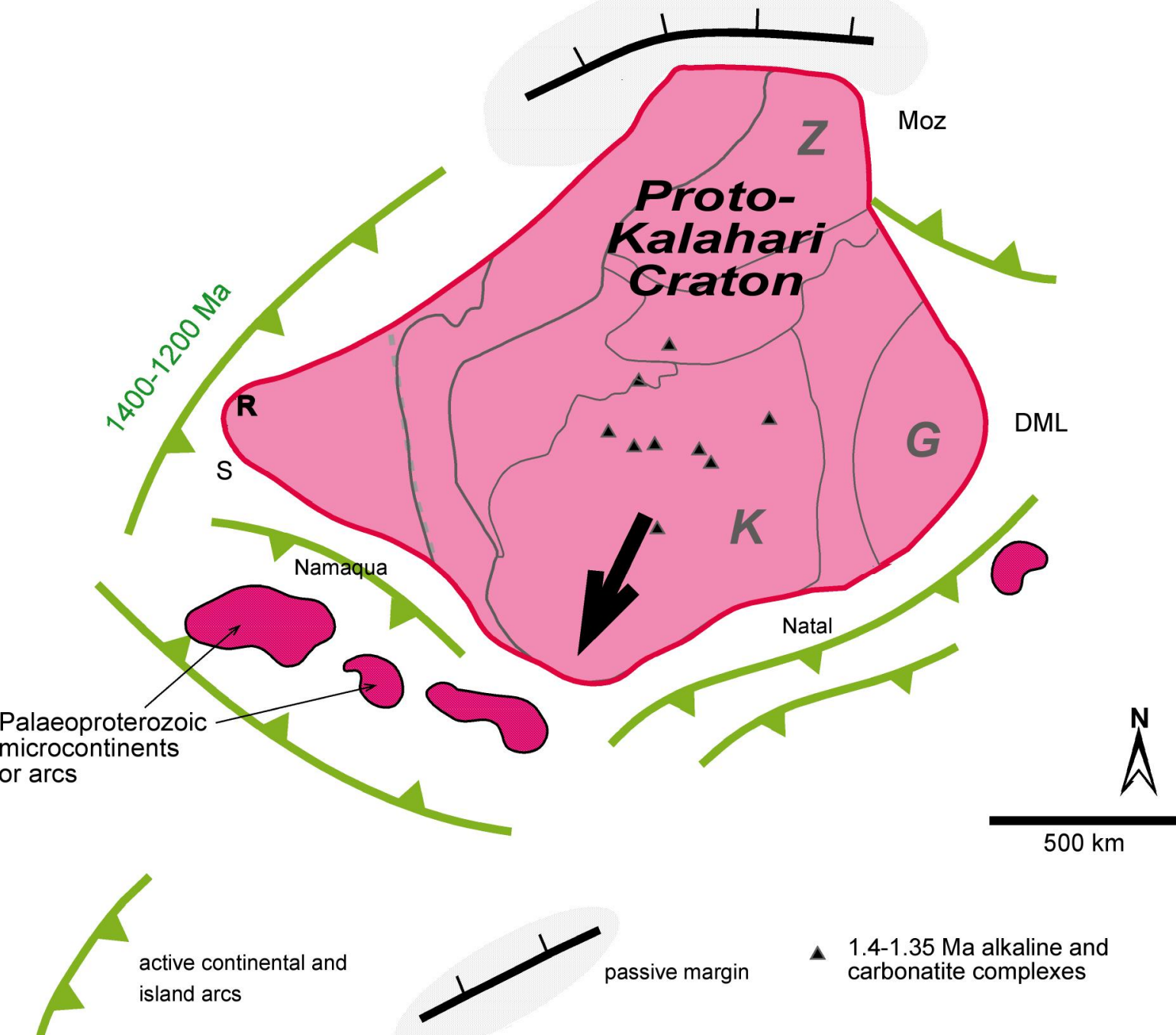


Fig. 4 : Jacobs et al.

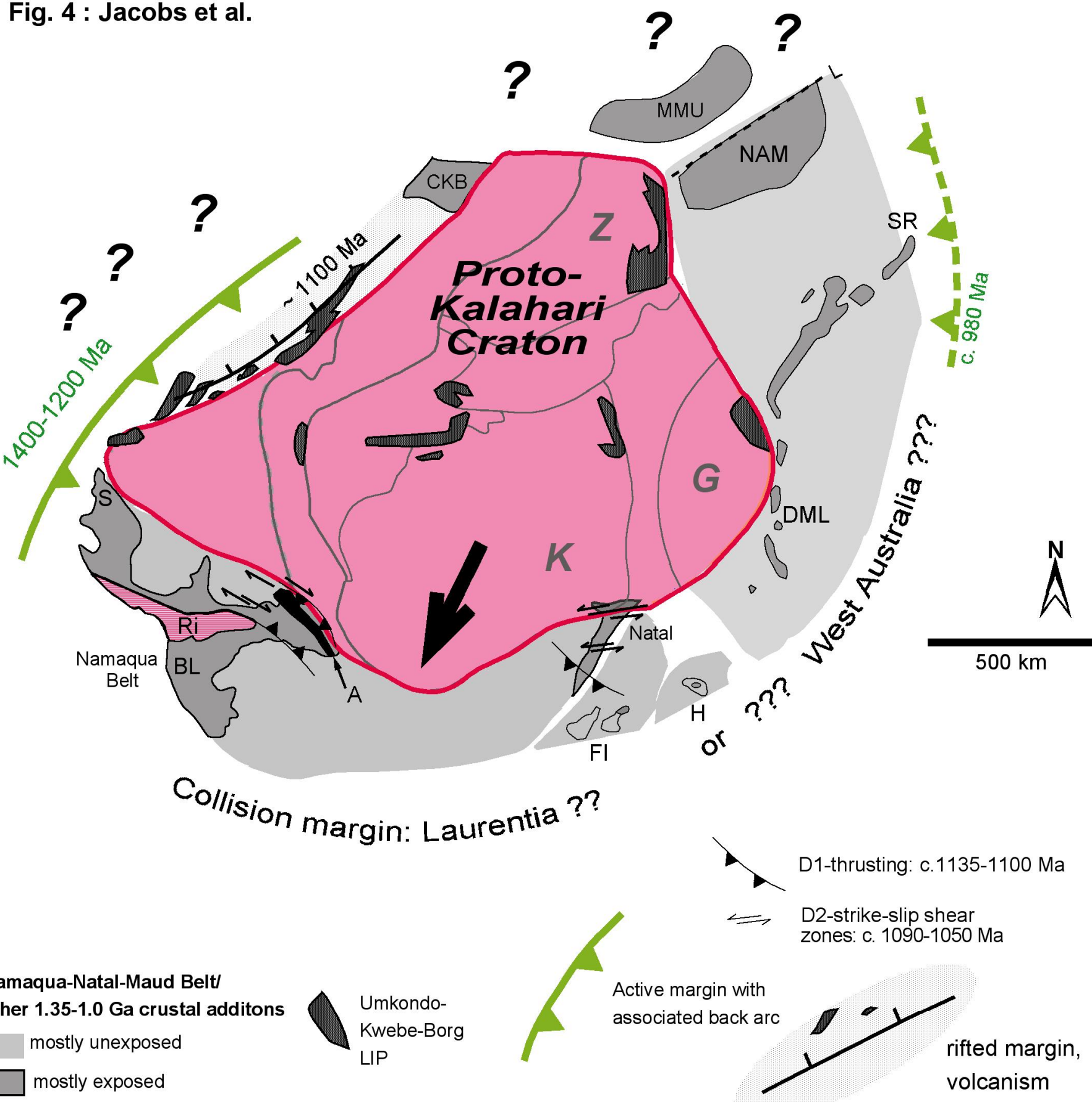


Fig. 5: Jacobs et al.

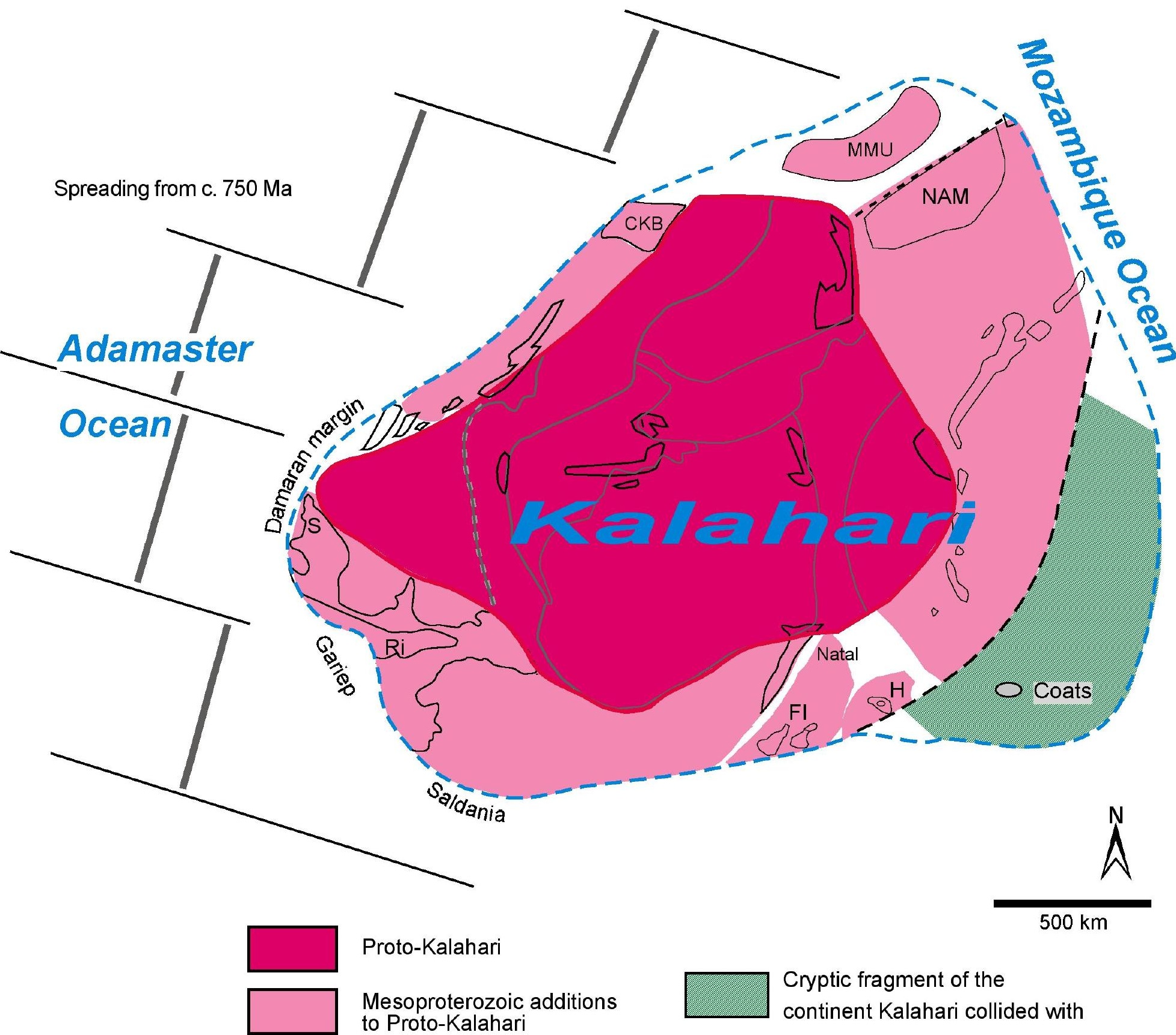


Jacobs et al., Fig. 7

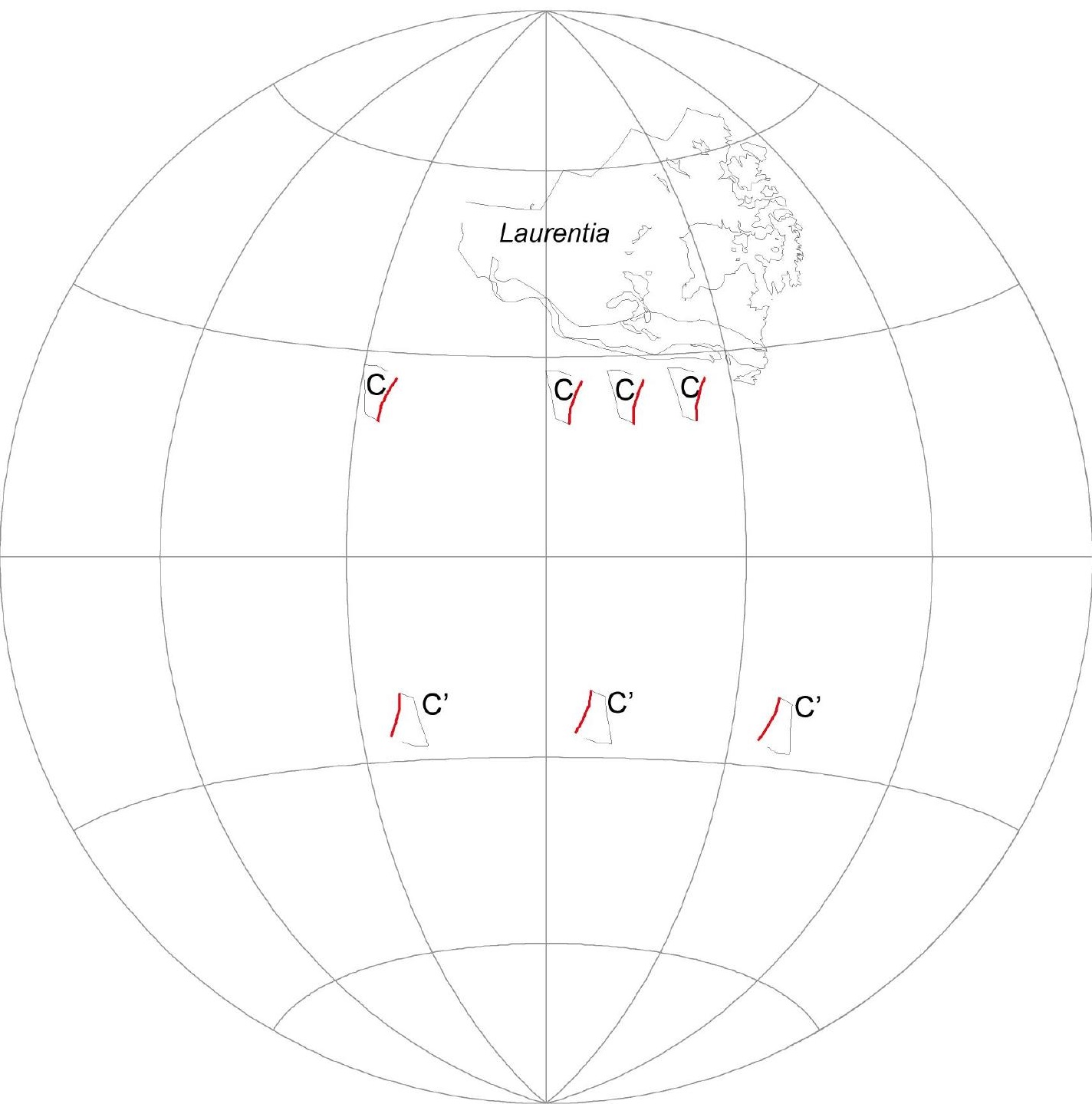


